\title{
The organophosphate pesticide -OP- malathion inducing thyroidal disruptions and failures in the metamorphosis of the Senegalese sole, Solea senegalensis
}

\author{
Juan B. Ortiz-Delgado ${ }^{1 *}$, Victoria Funes ${ }^{2}$ and Carmen Sarasquete ${ }^{1}$
}

\begin{abstract}
Background: Organophosphate pesticides-OP-, like malathion, can alter the normal functioning of neuro-endocrine systems (e.g., hypothalamus-pituitary-thyroid-HPT- axis), and to interfere on the thyroidal homeostasis. Through direct interactions with thyroid receptors, an/or indirectly via up-stream signalling pathways, from the HPT axis (i.e., negative feedback regulation), malathion possess the ability to affect integrity of thyroidal follicular tissue, and it can also block or delay its hormonal functioning. This insecticide can alter the majority of the ontogenetic processes, inducing several deformities, and also provoking decreases in the growth and survival patterns. The present study has been performed to determine the sublethal effects of malathion during the first month of life of the Senegalese sole, Solea senegalensis, and it is mainly focused on the metamorphosis phase. Different transcript expression levels (i.e. thyroid receptors, matrix and bone -Gla-proteins) and immunohistochemical patterns (i.e. thyroid hormones, osteocalcin, cell proliferation) have been analysed during the most critical phases of the flatfish metamorphosis, that is, through differentiation of thyroid system and skeletal development, migration of the eye, and further adaptation to benthic behaviours.

Results: In early life stages of the Senegalese sole, the exposure to the highest concentration of malathion ( 6 . $25 \mu \mathrm{g} / \mathrm{L})$ affected to the growth patterns, showing the exposed individuals, a reduction around 60 and $92 \%$ of the total length and the dry weigth, respectively. In paralell, a significant reduction of the thyroid follicles (i.e., size and number) it was also been recorded, in a dose-dependent way. Abnormal phenotypes induced in the exposed larvae, did not complete the process of metamorphosis, and displayed several morphological abnormalities and developmental disorders, which were mainly associated with the eye migration process, and with thyroidal and skeletal disorders (i.e., transcriptional and protein changes of thyroid hormones and receptors, and of matrix and bone Gla proteins distribution), that conduced to an inadequate adaptation to the benthic life.

Conclusions: In the Senegalese sole, the majority of the ontogenetic alterations induced by the exposure to malathion were mainly associated to the metamorphosis period, which is a thyroid-driven proccess. In fact, most crucial and transitional ontogenic events, appeared notably disturbed, for e.g., thyroid gland differentiation and functioning, migration of eye, skeletal development and benthonic behaviors.
\end{abstract}

Keywords: Eye, Malathion, Metamorphosis, Osteocalcin, Proliferation, Proteins, Skeleton, Senegalese sole, Thyroid, Transcripts

\footnotetext{
* Correspondence: juanbosco.ortiz@icman.csic.es

${ }^{1}$ Instituto de Ciencias Marinas de Andalucía-ICMAN, CSIC Campus

Universitario Río San Pedro, 11510 Puerto Real, Cádiz, Spain

Full list of author information is available at the end of the article
}

(c) The Author(s). 2019 Open Access This article is distributed under the terms of the Creative Commons Attribution 4.0 International License (http://creativecommons.org/licenses/by/4.0/), which permits unrestricted use, distribution, and reproduction in any medium, provided you give appropriate credit to the original author(s) and the source, provide a link to the Creative Commons license, and indicate if changes were made. The Creative Commons Public Domain Dedication waiver (http://creativecommons.org/publicdomain/zero/1.0/) applies to the data made available in this article, unless otherwise stated. 


\section{Background}

The intensive use of pesticides such as insecticides, herbicides, fungicides, acaricides, among others, has led to ubiquitous contamination, being present not only in soils, water-bodies and crops, but also in the atmosphere as fine airborne particles, as it has recently been reported by using an interesting and innovative green technology [1]. One of the most serious consequences of the increasingly use of pesticides is the chemical pollution of freshwater and estuarine ecosystems, which are the ultimate storehouse of their residues [2-4]. Due its high persistence and bio-accumulative properties, these synthetic chemicals affect behavioral and physiological systems of the aquatic inhabitants, particularly those of the fish [5]. Pesticides, even at very low concentrations provoke hazardous impacts on basal metabolisms. These harmful effects are expressed either, in terms of mortality, or by different alterations, such as retardation in growth, development and reproduction, among other physiological processes, depending on the physical and chemical properties of the pesticides, its concentrations, capability of degradation, and the ability of fish to metabolise them [6-8]. Natural and synthetic pesticides are used to kill unwanted organisms in crops, public areas, homes and gardens, and parasites. Many chemicals that have been identified as endocrine disruptors (EDCs) are pesticides, and several different effects linked to endocrine disruptions have been largely reported in invertebrates, fish, reptiles, birds and mammals [9-14]. Among many other environmental EDCs, pesticides can alter the normal functioning of the neuro-endocrine systems (e.g. the thyroid axis), and therefore these xenobiotics can interfere with endocrine homeostasis and dependenthormonal processes. Besides, pesticide induced thyroid disruptions can severely compromise different developmental processes, growth, fitness and survival of the exposed fish [4, 9, 11, 12, 15]. Disruptions of the thyroid status and functioning can occur through several steps, i.e. in the synthesis, regulation, metabolism, transport and action of the thyroid hormones/ THs [16, 17]. Pesticides can affect thyroid signalling by blocking, mimicking, or synergizing to the endogenous hormones, through direct thyroid receptor (TRs) interactions, and indirectly via upstream signalling pathways, by inhibiting hormonal synthesis $[13,18]$. In addition, many pesticides possess the ability to affect the thyroid gland integrity itself, such as it has been reported in different fish species [7, 19, 20].

As it is very well known, in vertebrates but most notably in anuran amphibians, and in flatfish species, the complex neuroendocrine-thyroid system is the main key for the progress of the metamorphosis, and this thyroidal axis serves to transduce environmental informations into a set of endocrine and sympathetic responses, that regulate specific alterations of the behavioural, morphological and physiological systems [21-23]. Flatfish metamorphosis culminates with the transition to definitive juvenile phenotype and behavior, and this transitional ontogenetic proccess is previously encompassed by the reorganisation and maturation of the digestive, respiratory, visual (e.g. eye migration) and neural systems, as well as noticeable changes in the skin-pigmentary patterns and skeletal and muscular structures, among other developmenal variations [22-28]. Although the molecular mechanisms and genes involved in the metamorphic processes have still not yet been fully elucidated, currently it is very known that the hypothalamus-pituitary-thyroid (HPT) axis mediates the metamorphosis of flatfish species, just as it does in amphibians [13, 22, 23, 29], among others. Accordingly, thyroid disruptions may alter and compromise the metamorphosis of flatfish, and therefore the viability, fitness and healthy survival of larvae and juveniles. The flatfish metamorphosis is one of the most critical ontogenetic developmental events, and also one of the most sensitive to environmental toxicants (i.e. chemicals, phytochemicals, etc.), and particularly against those endocrine disruptors targeting the thyroid axis $[9,22,30,31]$. In addition, thyroid hormones (THs) are involved in the most important physiological and ontogenetic processes, such as vision, feeding, behavior, metabolism, growth, pigmentation, ossification and development and differentiation of the cardiovascular, digestive and muscular systems, among others [14, 22, 23, 32]. Furthermore, during the flatfish ontogeny, some of the most critical and sensitive events are especially related with the development and differentiation of the eyes, and craniofacial structures, since they are essential target-organs for avoiding predators, locomotory performance and food intake [22, 31, 33-37]. In vertebrates, the eye and craniofacial developments are complex processes regulated by THs, and treatments with many thyroid disruptors result in malformations of eyes and head, reduced eye-sizes, and disruptions of retinal celllayers $[15,23,38]$. In this contex, the development and differentiation of photoreceptors occurs through direct regulation of thyroid hormones (THs); and thyroid receptors (TRs) are expressed in the outer nuclear layer (ONL) of the retina, which contains the differentiating photoreceptors [39, 40]. In addition, THs are required for normal skeletal development, and they have a crucial role in osteoblastic differentiation [41, 42]. It has been reported that reduced levels of THs cause growth inhibition of the cranial base of cartilage and bone, resulting in a wide and short face with an underdeveloped mandible [43].

On the other hand, organophosphate pesticides (OPs) are a group of synthetic chemicals, used for many 
domestic and industrial purposes. Over time, they have been the most commonly used as insecticides, accounting $50 \%$ of the global use, and they have been responsible for numerous pesticide poisoning [44]. The non-systemic and wide-spectrum organophosphate insecticide malathion [1,2-Di (ethoxycarbonyl)ethyl O,O-dimethyl phosphoro-dithioate], is one of the earliest organophosphate insecticides developed in 1950 and was first registered for using in 1956, by the United States Department of Agriculture (USDA), and it was regulated (Registration Eligibility Decision, RRD) by the United States Environmental Protection Agency (USEPA) [45]. Despite its ban by the European Commission, since June 2007 (Regulation EC 1376/07,47 07/389), malathion is still widely used in developing countries worldwide provoking harmful environmental problems in coastal areas, because of its runoff from agriculture and urban sources [4, 46, 47]. Under the present legislation, in Europe, the use of the OP pesticides is prohibited and, therefore these pollutants should not be present in the environment. However, in the last years, some data of pollution by OP pesticides have been registered in Mediterranean coastal areas $[48,49]$. Pesticides, such as malathion, dichlorvos, quinalphos, and other contaminants have been measured in some costal aquaculture systems [50]. Several studies have reported high malathion concentrations ranging from 2.62 to $105.2 \mu \mathrm{gL}^{-1}$ in different ground-water samples, from different worldwide areas [51, 52]. Additionally, the RASFF (Rapid Alert System for Food and Feed) from European Commission reported 13 notifications during 2006 to 2014 of pesticide residues, in fish fillets from Indian areas [53].

In different fish species, the OP malathion has been reported to alter the thyroid system, causing decreased thyrotropin (TSH) synthesis and secretion, as well as reduction of thyroid hormonal levels, which provoked serious disrupting effects in developmental and growth patterns, behaviours, fitness and survival $[2,4,7,9,54]$. A review about malathion toxicity and effects on fish (i.e. bioaccumulation, behavioural and neurotoxicant responses, histopathological and haematological alterations, respiratory responses, biochemical parameters, chromosomal damages, etc.) has recently been published [3]. In addition, in a recent study performed at the early life stages of the Senegalese sole, Ortiz-Delgado et al. [55] reported that the exposure to acute concentrations of malathion (i.e. at $72 \mathrm{~h}, \mathrm{LC} 50: 22.94 \mu \mathrm{g} / \mathrm{L}$; LOEC: $3.12 \mu \mathrm{g} / \mathrm{L}$ and NOEC: $1.6 \mu \mathrm{g} / \mathrm{L})$ altered the notochord and trunk musculature integrity, displaying noticeable changes of the composition of collagen fibers from the perinotochordal connective sheath, and other serious neural and somatic ontogenetic disorders.
In accordance with all of these referenced findings, and from many other existing reports, on the toxicity of malathion and its effects on different fish species, it has been hypothesized that most of the disruptive thyroidal responses induced by the OP- malathion, should alter the thansitional and complexity processes driven by the thyroid-axis; that is the metamorphosis process of this flatfish, and should also alter normal growth pattern, behavior and phenotype, as well as fitness and healthy survival of juveniles. Therefore, a subacute exposure to environmentally-relevant sub-lethal concentrations of malathion during the larval development of the Senegalese sole, S. senegalensis is analysed in the present study, by using several biological, biometric, molecular and cell markers. Thus, the aim of this work has been: i) To analyse the subacute effects of sub-lethal concentrations of the OP malathion, administered at the early life stages of the Senegalese sole, and particularly focused during the metamorphosis process, by analysing several disrupting effects targeted on thyroid follicles; eye/retina and skeletal development; and ii) To provide some insights into underlying molecular mechanisms, that are inducing abnormal metamorphosis, due to malathion exposure. To achieve this goal, three concentrations of malathion $\left(1.56,3.12\right.$ and $6.25 \mu \mathrm{gL}^{-1}$ ) have been tested during the first month of larval life (from $4 \mathrm{dph}$ until $30 \mathrm{dph}$ ). The growth patterns, and the effects on the eye differentiation and migration, as well as on the thyroid gland ontogeny and on the skeletal development were also analysed and discussed.

\section{Results}

\section{Growth patterns}

The growth pattern of the Senegalese sole, during the first month of larval life, in terms of total length (TL) and dry weight (DW) is represented in Fig. 1. The controls showed a typical allometric growth pattern, as well as an adequate larval development, and a normal organogenesis, with progressive and characteristic migration of one of the eyes. The percentage of larvae with correct migration of the eye ranged between $40 \%$ (at 20 $\mathrm{dph}$ ) and 100\% (at $30 \mathrm{dph}$ ) (Fig. 2). By increasing both the time of exposure and malathion concentrations, significant morphological and ontogenetic changes were registered during the first month of life. In fact, a delayed growth pattern was recorded in parallel with increases of the malathion concentrations tested, being the TL significantly reduced from $20 \mathrm{dph}$ onwards, when larvae were exposed to 1.56 and $3.12 \mu \mathrm{g} / \mathrm{L}$, and earlier (from $10 \mathrm{dph}$ onwards) in exposures at the highest concentration (at $6.25 \mu \mathrm{g} / \mathrm{L}$ ) assayed. At the end of the experimental period (at $30 \mathrm{dph}$ ), body length leveled off from $13 \mathrm{~mm}$ of TL in controls to approximately 

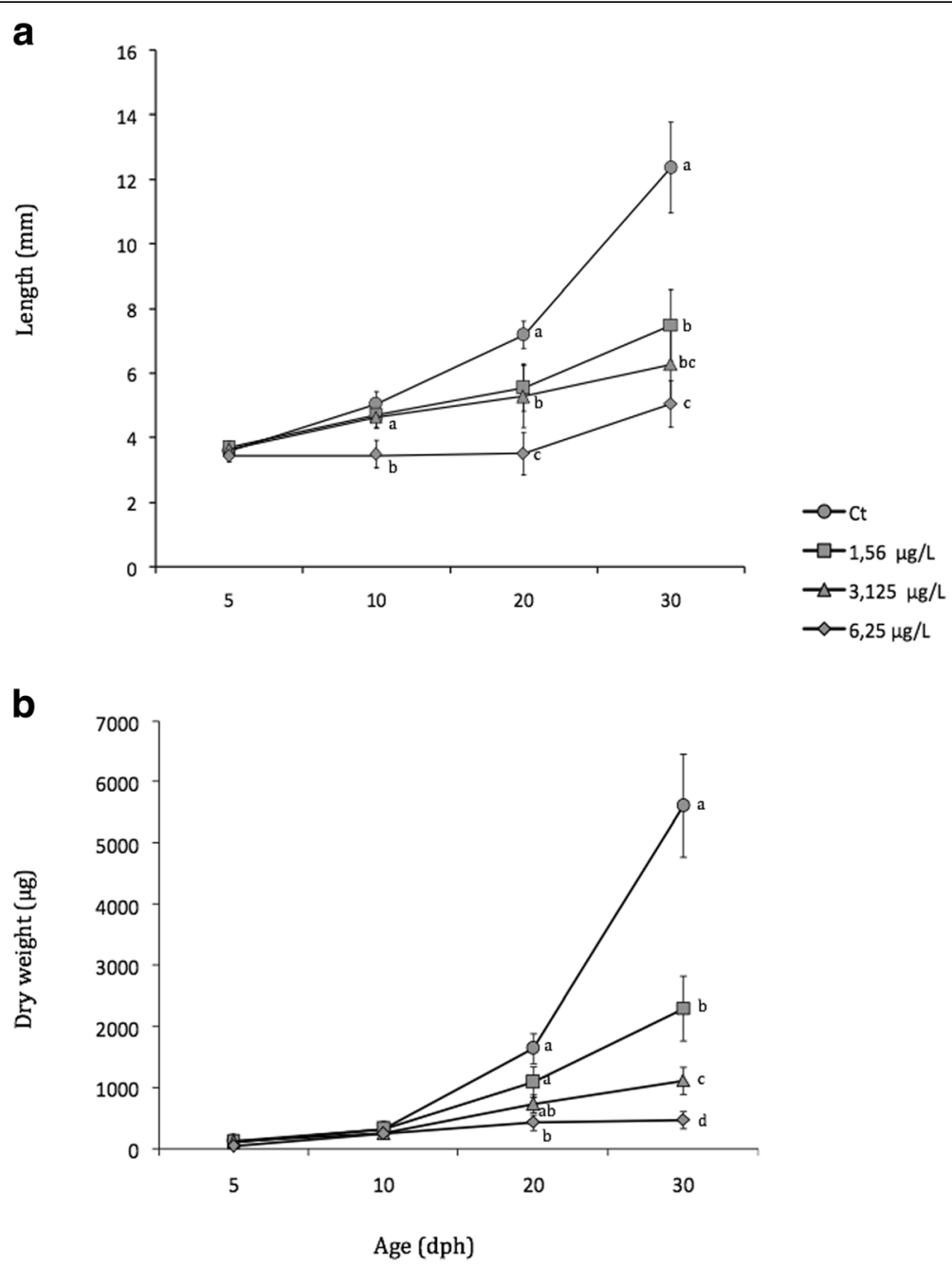

Fig. 1 Changes in total length (a) and dry weight (b) (mean \pm SD) of Solea senagalensis larvae exposed to different malathion concentrations. Different letters denote significant differences $(P<0.05)$ between control and malathion treatments at the same age

$6-8 \mathrm{~mm}$ in larvae from all malathion treatments (at 1.56, 3.12 and $6.25 \mu \mathrm{g} / \mathrm{L}$ ) (Fig. 1a). On the other hand, the DW was also significantly reduced at $30 \mathrm{dph}$, with malathion treatments of 1.56 and $3.12 \mu \mathrm{g} / \mathrm{L}$, and from $20 \mathrm{dph}$ onwards with the highest malathion concentration tested (at $6.25 \mu \mathrm{g} / \mathrm{L}$ ), showing a weight reduction up to $90 \%$ in exposed larvae at $30 \mathrm{dph}$, in comparison with controls (Fig. 1b).

The advancement of metamorphosis in terms of the eye migration is represented in Fig. 2. The malathion exposure significantly slowed the metamorphosis, in a time- and dose- dependent manner. At 1.56 and $3.12 \mu \mathrm{g} /$ L of malathion, statistically significant differences between controls and exposed larvae were registered from $13 \mathrm{dph}$ onwards, whereas at $6.25 \mu \mathrm{g} / \mathrm{L}$, significant changes were displayed earlier in the larval development (from $12 \mathrm{dph}$ onwards). In controls, at $30 \mathrm{dph}$, the index of eye migration $\left(I_{\mathrm{EM}}=5\right)$ was completed and fully normal and presented less advanced metamorphic stages, in a concentration-dependent manner, for those exposed fish ( $I_{\mathrm{EM}}: 2.95$ at $1.56 \mu \mathrm{g} / \mathrm{L} ; I_{\mathrm{EM}}: 2.19$ at $3.12 \mu \mathrm{g} /$ $\mathrm{L}$ and $I_{\mathrm{EM}}: 0.44$ for $6.25 \mu \mathrm{g} / \mathrm{L}$ ) (Fig. 2 a to $\mathrm{d}$ ).

Regarding the phenotypes, the larvae exposed to malathion did not complete the metamorphosis process and displayed, at the end of experimental period, abnormal morphologies showing eye migration failures and pigmentary disorders (Fig. 3 a to c). Larvae exposed to intermediate concentration (at $3.12 \mu \mathrm{g} / \mathrm{L}$ ) showed the lack (bilaterally symmetric), or an incomplete eye migration (at $1.56 \mu \mathrm{g} / \mathrm{L}$ ), but displayed morphological characteristics and normal lateralized behaviors, settled with their left-side on the botton, such as it is observed in the controls (Fig. $3 \mathrm{~b}$ and c). Most larvae at $6.25 \mu \mathrm{g} / \mathrm{L}$ showed (74\%) the metamorphic Stage 0 without signs of eye migrations. These larvae, still planktonic, showed a morphological pattern similar to that observed in pre-metamorphic larvae, with the absence of 


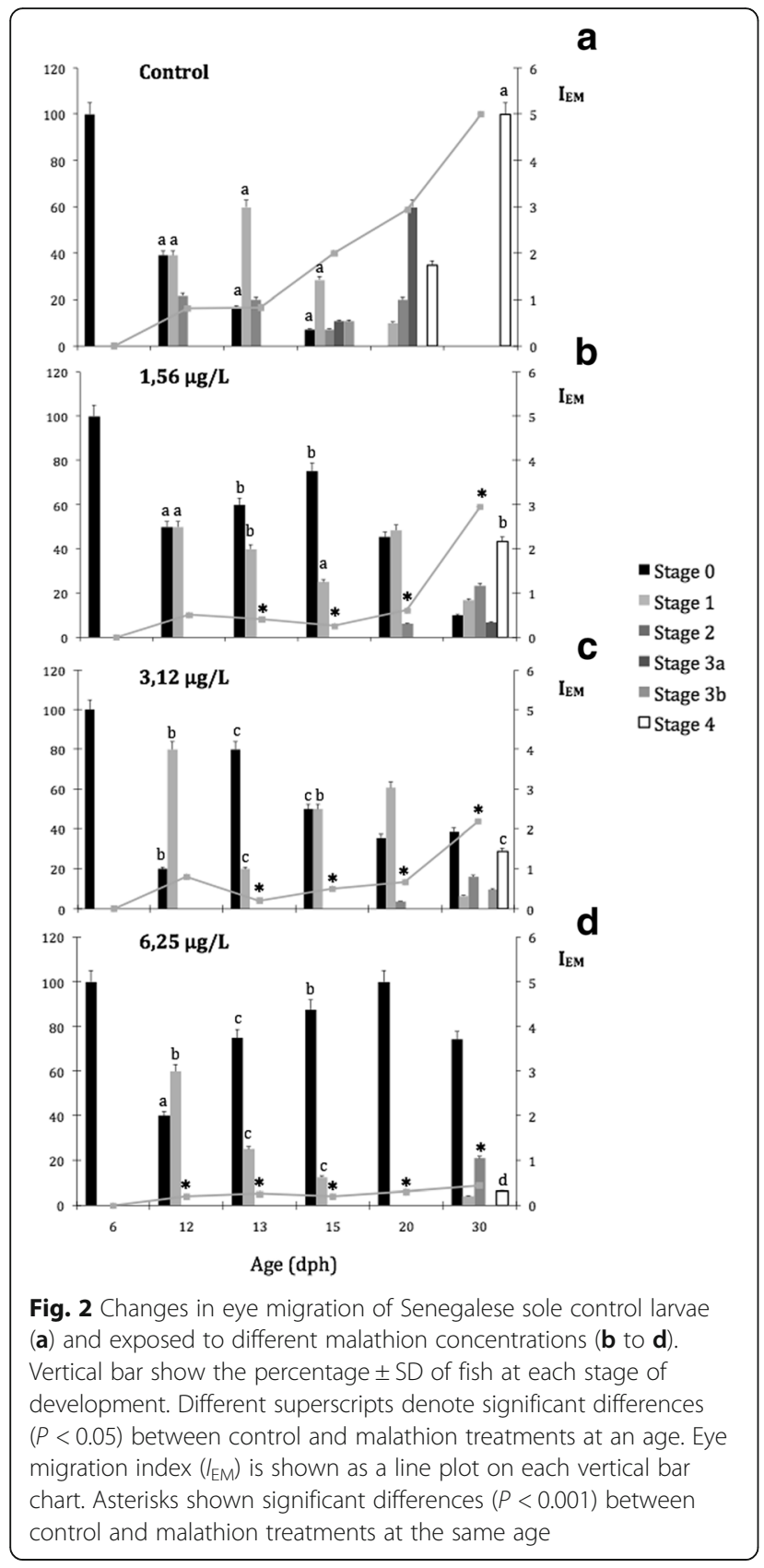

morphological characteristics or normal lateralized behaviours, which are necessary for the adaptation to benthic- life (Fig. 3d).

\section{Effects on the thyroid gland development}

Morphologically, all controls showed a thyroid gland dominated by larger follicles lined by cuboidal or columnar cells depending on their secretory activity, that surrounded an inner colloidal lumen (Fig. 4a). During the larval development, the thyroid follicles increased in number and size up to 6-7 follicles that were visible at $30 \mathrm{dph}$ (Table 1).
In malathion exposed larvae, a significant reduction in both size and number of thyroid follicles was recorded in a dose-dependent way (Fig. $4 \mathrm{~b}$ to d). Thus, at $30 \mathrm{dph}$ the size of the thyroid follicles ranged from $75,43 \mu \mathrm{m}$ in controls (Fig. 4 a; Table 1) until 69.8, 53.2 and 35,2 $\mu \mathrm{m}$ in the different malathion treatments (Table 1), at 1.56 (Fig. 4) b, 3.12 (Fig. 4)c and 6.25 (Fig. 4)d $\mu$ g/L, respectively. Additionally, the number of the thyroid follicles was also significantly reduced, ranging from 6 to 7 in control larvae up to 2-3 follicles in the exposures of $6.25 \mu \mathrm{g} / \mathrm{L}$ (Fig. 4 a to d; Table 1). At this higher concentration, epithelial cells of the thyroid follicles seemed to be atrophied, with signs of hyperchromatism (Fig. $4 \mathrm{~d}$ ). Parallely to the reduction in size and number of follicles, a decreased functionality of the thyroidal follicles was detected by means of immunohistochemistry. Thus, whereas in controls at $30 \mathrm{dph}, \mathrm{T}_{4}$ immunostaining was evidenced in the thyrocytes, within colloid and in plasma contents, from the external irrigating blood vessels surrounding the thyroid follicles (Fig. 4 e and f), in malathion exposed larvae a weak immunostainning affinity for $\mathrm{T}_{4}$ was only present in the colloidal content. Additionally, thyrocytes or surrounding blood vessels were devoid of $\mathrm{T}_{4}$ immunostaining (Fig. $4 \mathrm{~g}$ and $\mathrm{h}$ ). Similar results were recorded for $\mathrm{T}_{3}$ immuno-localisation (data not shown).

The gene expression transcript levels of the thyroid receptor- $\beta(\operatorname{Tr} \beta)$, it has been scarcely expressed before starting the metamorphosis (between 4 and $11 \mathrm{dph}$ ) in the controls. During the larval development, $\operatorname{Tr} \beta$ transcripts increased progressively from $13 \mathrm{dph}$ onwards, displaying the highest $\operatorname{Tr} \beta$ expression levels at the end of metamorphosis stage, i.e. 18 fold increases of $\operatorname{Tr} \beta$ transcripts at 20 $\mathrm{dph}$, in comparison with the pre-metamorphosis phase, and high levels of expression were also registered at the post-metamorphosis (at $30 \mathrm{dph}$ ). On the other hand, malathion exposed larvae exhibited between 42 and 19 fold lower $\operatorname{Tr} \beta$ mRNA levels $(p<0.05)$ than controls, at 20 and $30 \mathrm{dph}$, respectively (Fig. 5a). Furthermore, the $\operatorname{Tr} \beta$ transcripts were also detected by in situ hybridization in different cell-types of the $S$. senegalensis, in the thyroidal cells, as well as in several somatic organs-systems and tissues, eg., digestive, heart, skeletal and muscle structures (Fig. $5 \mathrm{~b}$ and c).

\section{Effects on skeletal development}

The gene expression patterns of the OC and MGP and protein accumulation were analysed in both, the controls and malathion exposed fish. The progress of ossification and the changes induced in response to different malathion treatments were also studied by means of the Alcian blue and Alizarin red (AA/AR) staining. In controls, the expression levels of both $O c$ and $M g p$ mRNA transcripts were precociously registered during the metamorphosis (from 4 

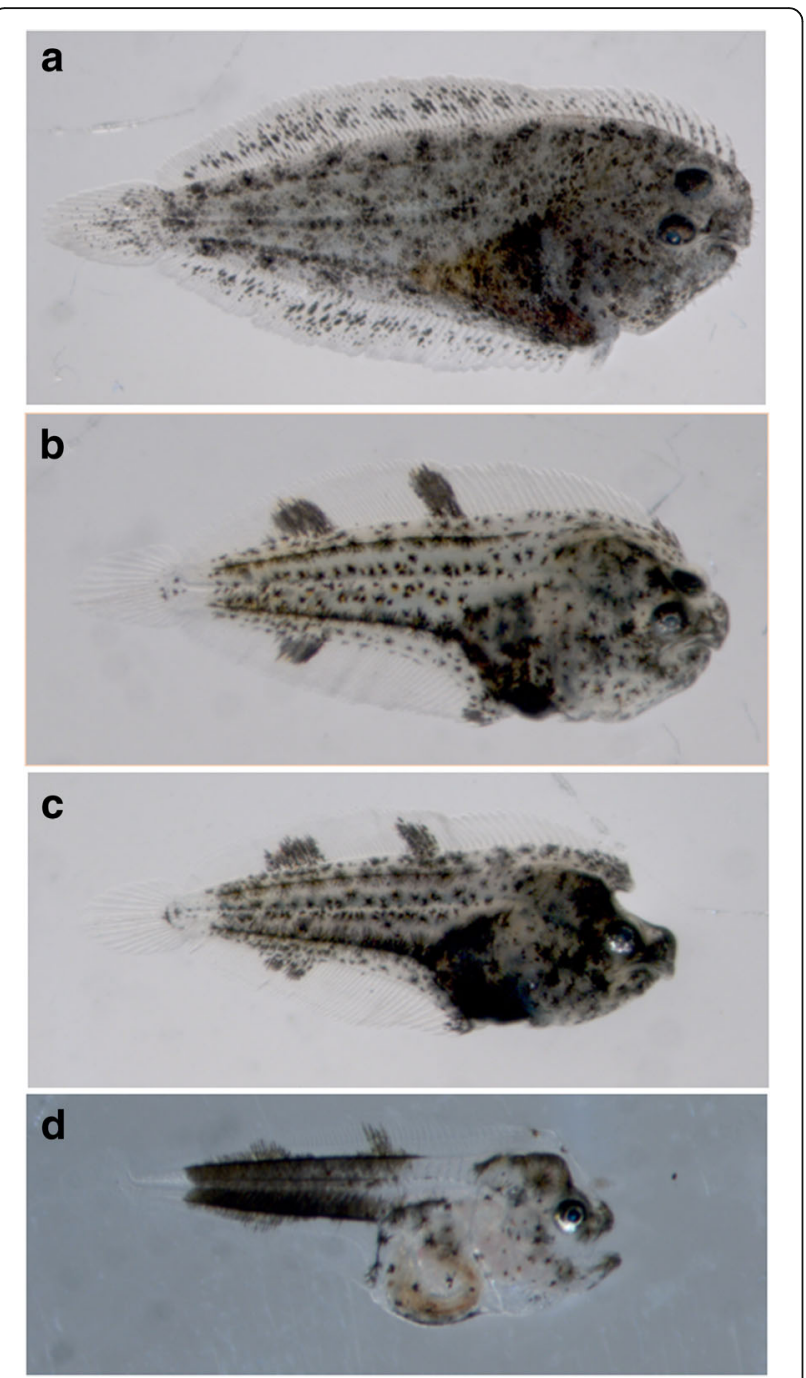

Fig. 3 Morphological aspects of Senegalese sole larvae at $30 \mathrm{dph}$. Note the different phenotypes in control (a) and 1.56 (b), 3.12 (c) and 6.25 (d) $\mu \mathrm{g}$ malathion/l

dph onwards) with lower transcript levels for Mgp than for $O c$, until $15 \mathrm{dph}$, in which significant increased levels of both trancripts were evidenced. At the end of metamorphosis and postclimax-stages (at 20-30 dph), transcript mRNA levels slightly decreased for $M g p$, however, the Oc trancripts remained at high levels of expression (Fig. 6 a and b). In malathion exposed specimens, a strong down-regulation of $O c$ mRNA transcript levels was detected from $15 \mathrm{dph}$ onwards, in a concentration-dependent manner (Fig. 6a) for all assayed conentrations, whereas the mRNA Mgp transcripts displayed a significant peak of induction at $11 \mathrm{dph}$ (3-fold increases) and a moderate although significant down regulation of $M g p$ expression levels from $13 \mathrm{dph}$ onwards was recorded in comparison with the typical normal baseline expression patterns of the controls (Fig. 6b). Surprisingly, no appreciable differences in the tissue-localisation of $O c$ and $M g p$ transcripts were detected in cartilage and bone structures, from both controls and malathion exposed fish, as detected by in situ hybridization (data not shown).

The AA-AR staining revealed that sublethal exposure to malathion provoked a delay in bone development and ossification processes during development of the Senegalese sole (Fig. $6 \mathrm{c}$ to h). In controls, at 30dph, an extended alizarin red staining was observed in several structures: lower and upper jaws, cranial bones, sphenoid, ceratobranchials, cleithrum, mesethmoid, lateral ethmoid, vertebral centra, neural and haemal spines (Fig. 6 c, e and g). However, in larvae exposed to the highest malathion concentration (at $6.25 \mu \mathrm{g} / \mathrm{L}$ ) the alizarin red staining was restricted to neural and haemal spines, cleithrun, ethmoid, ceratobranchials, lower and upper jaws, while cranial bones or sphenoid, caudal fin complex, dorsal and ventral pherigophores and fin rays still remained stained in blue colour, indicating a cartilage composition with specific affinity to Alcian Blue (Fig. $6 \mathrm{~d}$, $\mathrm{f}$ and $\mathrm{h}$ ).

In the Fig. 7 is graphically represented the immunohistochemical distribution of the OC (Fig. 7 a to d) and MGP (Fig. 7 e to h) proteins, in juveniles of the senegalese sole, from controls and malathion exposed specimens at $30 \mathrm{dph}$. In the controls, the $\mathrm{OC}$ displayed a positive immunosignal mainly in the matrix of skeletal structures already calcified or under calcification, such as neural and haemal spines and in perichordal ossification zones from the head and bucoparhyngeal cavity, among others (Fig. 7 a and c). However, in exposed larvae (at $6.25 \mu \mathrm{g} / \mathrm{L})$ no OC- immunostaining was registered (Fig. $7 \mathrm{~b}$ and d). The MGP was also accumulated in the controls, as for instance, in the mineralizing matrix of endochondral and intramembranous calcifyng bones such as vertebrae and cranial structures and in the calcified matrix below the trabecula. The MGP immunostaining was also located in the mineralizing branchial arches, and in non-mineralized walls (endothelia) of the vascular system (aorta and cardiac arterial bulbus) (Fig. 7 e and g). Interestingly, in exposed specimens (at $6.25 \mu \mathrm{g} /$ L) MGP was located in the same areas as in the controls, but showing a weaker immunostaining intensity-pattern (Fig. $7 \mathrm{f}$ and $\mathrm{h}$ ).

\section{Eye development and disruptions}

At the end of the experimental period (at 30dph), the larvae exposed to malathion displayed a reduction of the eye-size, and also a minor pigmentation pattern of the retinal pigmented layer (RPE) (Fig. 8a to d). In addition, the pigmentary epithelium displayed a significant reduction, of its thickness, in a concentration-dependent manner (Fig. 8e). Thus, in controls (30 dph), the eyes had a pigmentary epithelium of an average thickness of $43 \mu \mathrm{m}$, which significantly decreased to $12 \mu \mathrm{m}$, in those larvae 

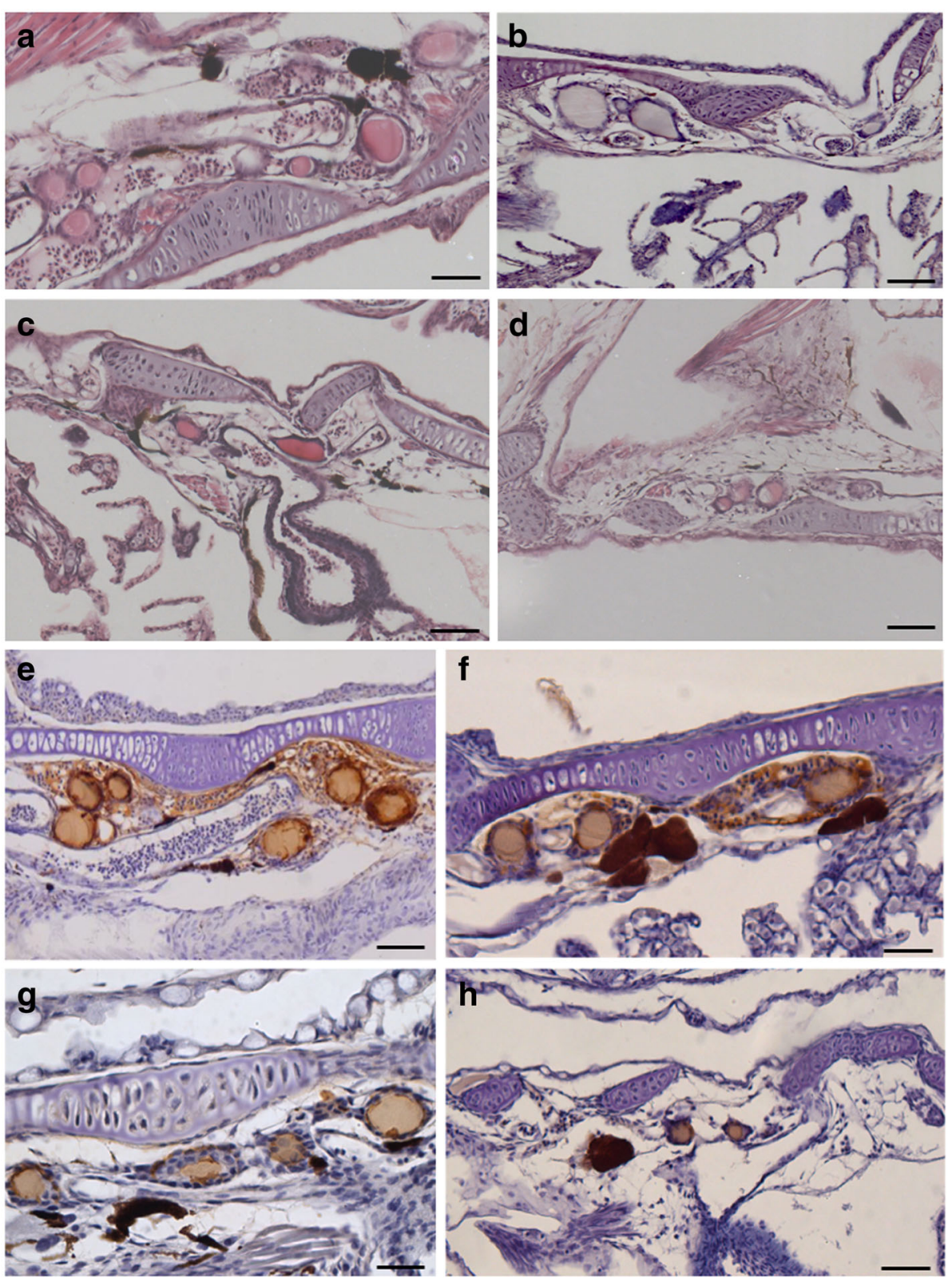

Fig. 4 (a to d) Tissue sections of thyroid gland of Senegalese sole at 30 dph showing thyroid follicles from controls (a) and 1.56 (b), 3.12 (c) and (6.25) malathion exposed larvae: a Control specimens showing a typical distribution of thyroid follicles around the ventral aorta. $\mathbf{c}$ to $\mathbf{d}$ Thyroid gland from malathion exposed specimens showing a reduction in number, size and epithelial height of thyroid follicles in comparison with controls. e to $\mathbf{h ~} \mathrm{T}_{4}$ immunolocalisation in Senegalese sole larvae at $30 \mathrm{dph}$ : e control and $\mathbf{f} 1.56 \mu \mathrm{g} / \mathrm{L}$ malathion exposed larvae showing positive staining in thyrocytes and colloid content, and in plasma content from vasculature; $\mathbf{g} 3.12$ and $\mathbf{h} 6.25 \mathrm{\mu g} / \mathrm{L}$ malathion exposed larvae showing a weak $T_{4}$ immunostaining in the colloidal content but not in the thyrocytes, neither in the plasma content. Scalebar represents $300 \mu m$

Table 1 Differences in number and size $(\mu \mathrm{m})$ of thyroid follicles after malathion exposure

\begin{tabular}{|c|c|c|c|c|c|c|}
\hline \multirow{2}{*}{$\begin{array}{l}\text { Number/Size of follicles (mean } \pm \text { SEM) } \\
\text { Control }\end{array}$} & \multicolumn{2}{|c|}{$13 \mathrm{dph}$} & \multicolumn{2}{|c|}{$15 \mathrm{dph}$} & \multicolumn{2}{|c|}{$30 \mathrm{dph}$} \\
\hline & 2 & $25,6 \pm 3.2$ & $3-4$ & $26,39 \pm 2.86$ & $6-7$ & $75,44 \pm 8.45$ \\
\hline $1,56 \mu \mathrm{g} / \mathrm{L}$ & 2 & $24,55 \pm 3.4$ & $2-3$ & $22,44 \pm 1.98$ & $5-6$ & $69,83 \pm 6.25$ \\
\hline $3,12 \mu \mathrm{g} / \mathrm{L}$ & 1 & $20,22 \pm 2.4$ & $2-3$ & $18,29 \pm 1.99$ & $3-4$ & $53,2 \pm 3.23$ \\
\hline $6,25 \mu \mathrm{g} / \mathrm{L}$ & 1 & $19,17 \pm 1.9$ & 2 & $21,24 \pm 3.4$ & $2-3$ & $35,17 \pm 1.9$ \\
\hline
\end{tabular}



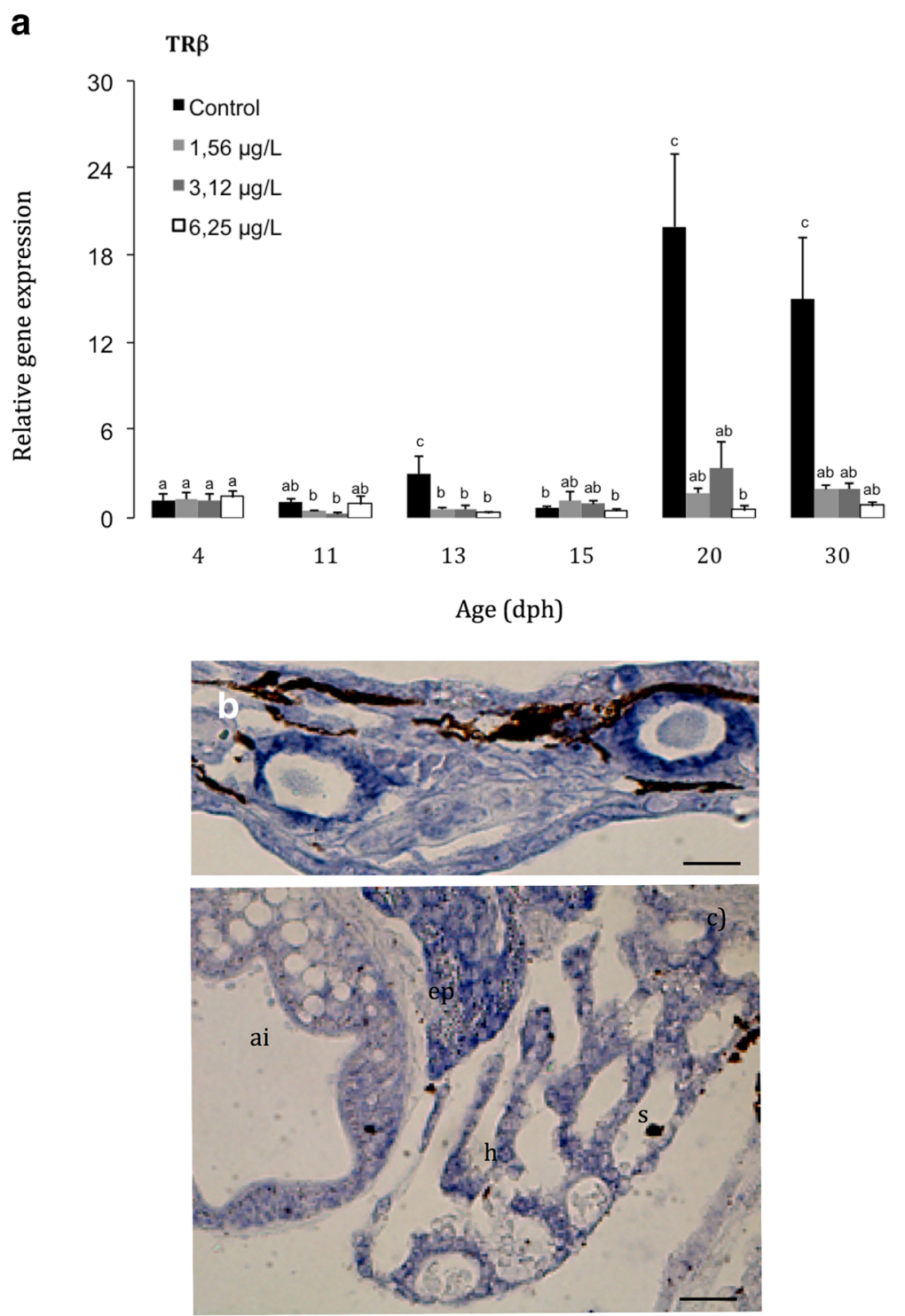

Fig. 5 a Relative expression of the thyroid receptor at different developmental stages during the metamorphosis process of the Senegalese sole; Tissue detection of $\operatorname{Tr} \beta$ in thyroidal cells $\mathbf{b}$ and in different somatic tissues $\mathbf{c}$ by in situ hybridization. Scalebar represents $300 \mu \mathrm{m}$. Ai: anterior intestine; S: sinusoids; h: hepatocytes; ep: exocrine pancreas

exposed to the highest $(6.25 \mu \mathrm{g} / \mathrm{L})$ malathion concentration (Fig. 8e). Measurements of the lens and from the other retinal cell layers (ONL, OPL, INL, IPL, GCL) revealed no significant differences, between controls and treatments (data not shown). On the other hand, the relative eye-size corrected for total length (TL) significantly increased in those larvae exposed to the highest malathion concentration (at $6.25 \mu \mathrm{g} / \mathrm{L}$ ), in larvae at 20 $\mathrm{dph}$, and for those larvae exposed to all the concentrations assayed at 30dph (Fig. $8 \mathrm{f}$ and g). Nevertheless, the eye-size expressed as the longest eye-diameter, gradually decreased as malathion concentration increased, being the eye diameter in malathion exposure at $6.25 \mu \mathrm{g} / \mathrm{L}$, between 1,4 and 2 -fold lower in comparison with the controls, at 20 and $30 \mathrm{dph}$, respectively (Fig. $8 \mathrm{~h}$ and i).

The immunohistochemical detection of proliferative cells, by using PCNA (i.e. proliferating-cell nuclear antigen) antibody revealed cell proliferation patterns in both, the retinal INL and in the ONL layers in malathion exposed fish, at $30 \mathrm{dph}$ (Fig. 9 a to d) when compaing to controls. Cell proliferation quantified as PCNA index significantly increased in both, the inner and the outer nuclear retinal layers, in the larvae of the Senegalese sole exposed to malathion in a dose-dependent manner (Fig. 9 e and f), during the first month of life. 


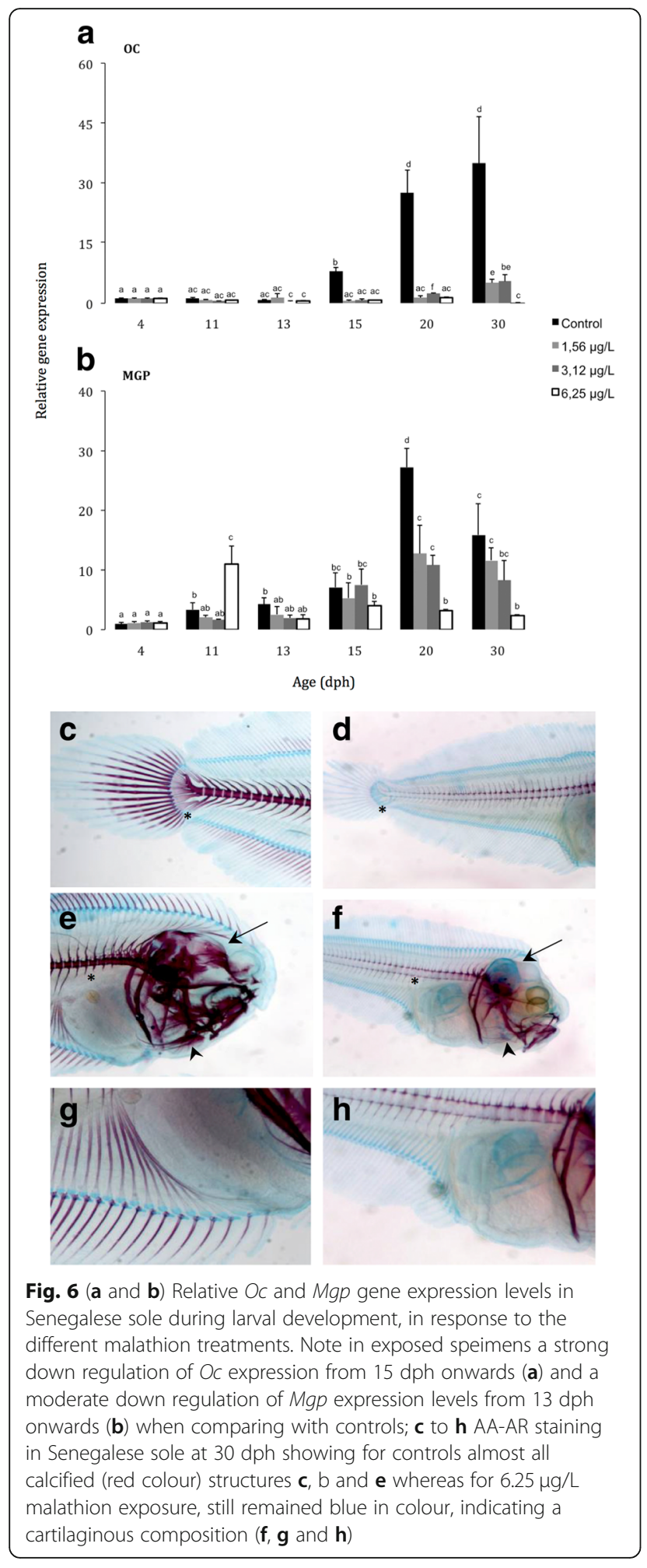

\section{Discussion}

Many environmental chemical contaminants, phytochemicals, and other natural and synthetic xenobiotics, that are known as typical endocrine-disrupting chemicals (EDCs), or acting as selective estrogen receptor modulators (SERMs), can affect wildlife and humans by interfering with endocrine homeostasis and hormonal processes, e.g. oestrogen or thyroid signaling acting through the hypothalamus-pituitary-thyroid (HPT) axis $[16,17,22]$, among others. Indeed, many of the EDCs act interfering with the thyroid function and/or blocking different signals of the thyroid cascade, i.e., hormones, receptors, enzymes, transporters, etc., [9, 31, 56]. Accordingly, in this context, the organosphosphate pesticide (OP) malathion, that is a specific inhibitor of the enzyme acethylcholinesterase (AchE), may act interfering with sensory receptors, i.e. chemoreception, especially olfaction and vision [15]. In addition, in fish species many behaviors are affected by the disruption of the neuro-endocrine system, because it is very sensitive to different contaminants, enclosing OP pesticides, that are also known acting as typical endocrine-thyroid (and oestrogenic)-disruptors $([9,57,58]$. The OP malathion has been reported to disrupt the thyroidal homeostasis, and to compromise fish growth, behavior and fitness, as well as to alter the larval development, cell-tissue differentiation, metamorphosis, reproduction, and healthy survival $[2,4,9,13,14,55]$. On the other hand, in vertebrates, but most particularly in anuran amphibians, as well as in fish, especially in Pleuronectiform flatfish species, such as the Senegalese sole, the metamorphic process by which a symmetrical larva becomes an asymmetric juvenile, is a thyroid-driven process, although many other endocrine signals and different biotic and abiotic factors also influence this complex-process [9, 13, 21-23, 35]. Interestingly, the flatfish metamorphosis is accompanied by an extensive craniofacial remodeling and migration of one eye, among other ontogenetic changes and biological, behavioral and ecological adaptations [22, 23]. In flatfish species, the most common developmental abnormalities include lack of eye migration, bone deformities, and pigmentation disorders, which have been related with zooctechnical procedures, genetic and nutritional factors, and environmental contaminants $[14,22,33,59,60]$, among others.

\section{Effects of malathion on growth patterns}

Ecotoxicological purposes often evaluate variations of growth patterns, because it reflects different molecular and cellular responses, as one easily measurable biometric parameter [61, 62]. Considerable number of reports, on retardation and decreases in fish growth, following exposure to pesticides and other chemicals are available [63-67]. Particularly, the OP pesticide malathion induced shortening of body length, as well as circulatory and collagen defects in different fish species, enclosed early lifes stages of the Senegalese sole [55, 68, 69]. In zebrafish embryos, the exposure to malathion (at $3 \mathrm{mg} /$ L), reduced the body-lengths up to $80 \%$ with respect to 

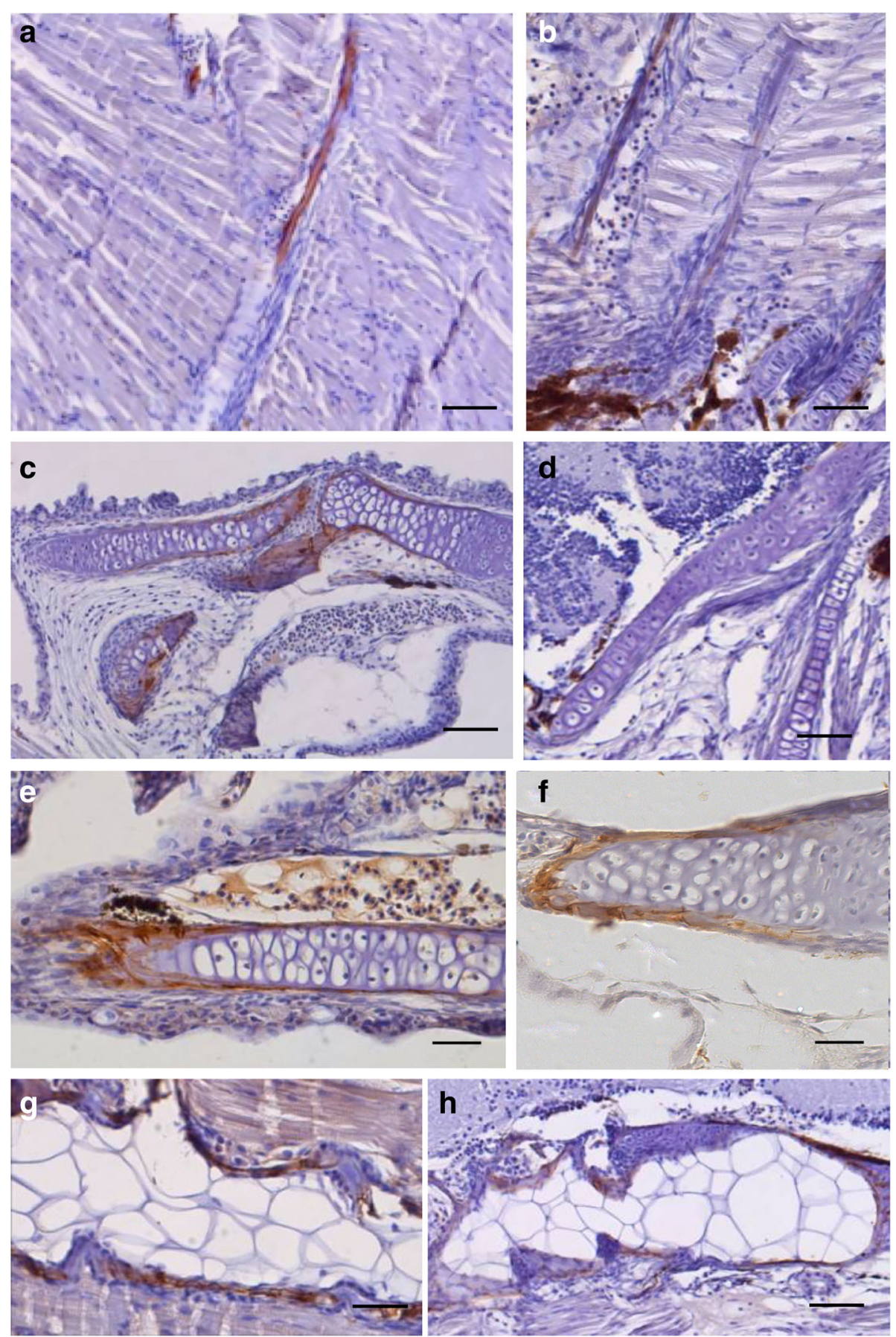

Fig. 7 Immunohistochemical distribution of OC (a to $\mathbf{d}$ ) and MGP (e to $\mathbf{h}$ ) proteins in juvenile specimens of the Senegalese sole controls and malathion ( $6.25 \mu \mathrm{g} / \mathrm{L})$ exposed specimens at $30 \mathrm{dph}$. Scalebar represents: a), b), e) to h) $300 \mu \mathrm{m} ; \mathbf{c}$ and d), $100 \mu \mathrm{m}$

the controls [63]. In the catfish, Clarias batrachus, exposed to malathion $(0.001 \mathrm{mg} / \mathrm{L})$, Lal [2] reported a significant decrease in the body and ovarian weights, during different phases of the reproductive cycle. Similarly, in the present study, the exposure to malathion affected the Senegalese sole growth patterns, in terms of total length (TL) and dry weigh (DW) in a dose dependent-way. In fact, the exposure to the highest malathion concentrations (at $6.25 \mu \mathrm{g} / \mathrm{L}$ ) reduced significantly the length and weight (up to 60 and 92\%) with respect to the controls, respectively. Among malathion's mechanisms implicated in reduction of fish growth, and in the ontogenetic developmental alterations, several dependent thyroidal disrupting effects have been pointed 

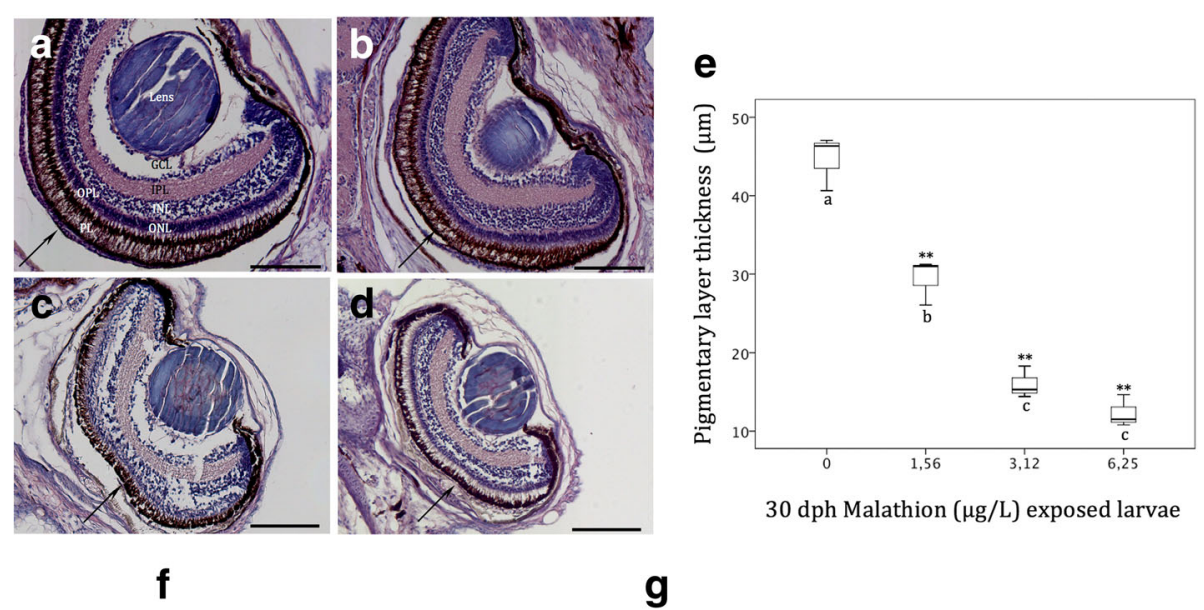

$30 \mathrm{dph}$ Malathion $(\mu \mathrm{g} / \mathrm{L})$ exposed larvae
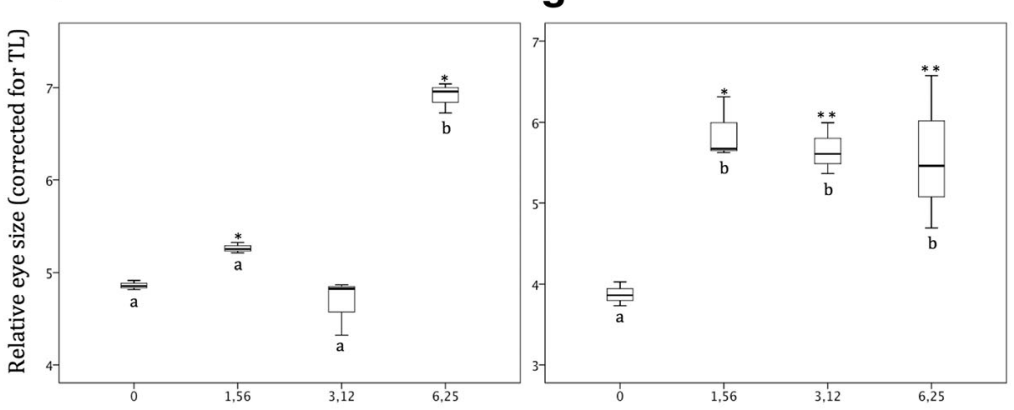

\section{h}

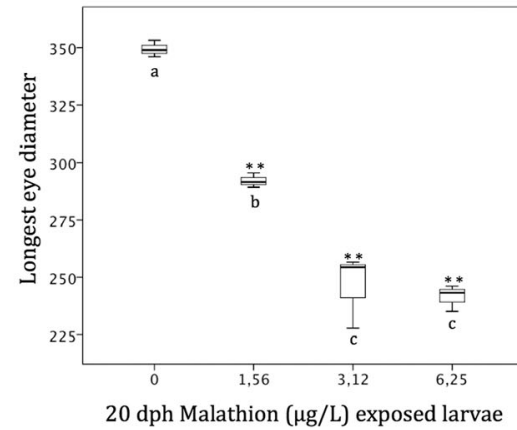

i

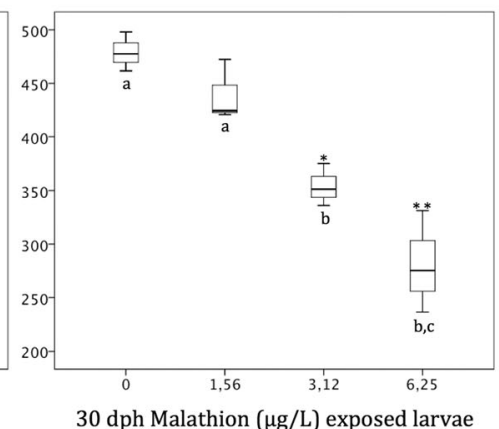

Fig. 8 (a to d) Histological sections of the Senegalese sole larvae at $30 \mathrm{dph}$, showing the different retinal layers from controls (a), and from 1.56 (b), 3.12 (c) and 6.25 (d) $\mu \mathrm{g} / \mathrm{L}$ malathion exposed organisms. Note reduction in size as well as in thickness of the pigmentary epithelium; e Changes in pigmentary layer thickness $(\mu \mathrm{m})$ in response to the different treatments; Eye size corrected for total body length of larvae at 20 (f) and 30 (g) dph; Changes in the longest eye diameter at 20 (h) and 30 (i) dph in response to the different treatments. Different letters indicate statistically significative differences between treatments. $\left({ }^{*}=P<0.05 ;{ }^{* *}=P<0.01\right)$. Scalebar represents $100 \mu \mathrm{m}$

out. It has been suggested that malathion not only arrests the $\mathrm{T}_{4}$ secretion, but it also inhibits the conversion of $T_{4}$ into $T_{3}$. Besides, it has been reported that $T_{3}$, increased the growth patterns in the yearling coho salmon, whereas $\mathrm{T}_{4}$ enhanced food consumption [70, 71]. In Clarias batrachus exposed to malathion, Lal [2] reported a drastic reduction in the body-weight, as well as in the food intake due to a disruption of the endocrine machinery associated with the regulation of food-consumption and its metabolism, what provoked a growth retardation. In addition, the exposure to malathion disrupted the endocrine funntioning, and the olfactory sensation responsible for food uptaking, and gustatory feeding behavior, which ultimately leads to retardation of the fish growth [7].

On the other hand, in flatfish species, as the Senegalese sole, the progression of the metamorphosis is analysed by the position of the left-eye, and well evaluated by means of the eye migration index $\left(I_{\mathrm{EM}}\right)[34,72]$. In the present study, this $I_{\mathrm{EM}}$ showed significant differences after exposure to malathion in a dose-dependent manner. In this context, $I_{\mathrm{EM}}$ was delayed from $13 \mathrm{dph}$ 


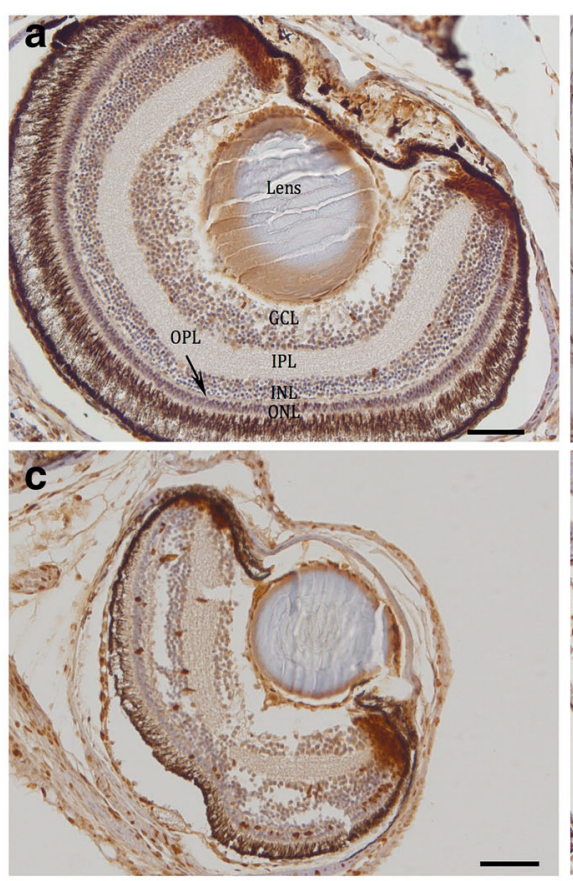

e

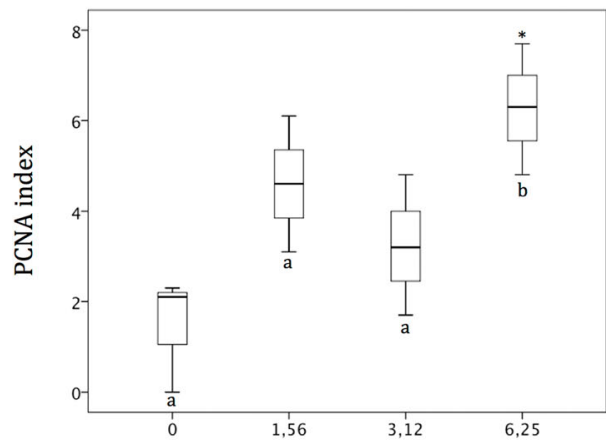

INL of $30 \mathrm{dph}$ Malathion $(\mu \mathrm{g} / \mathrm{L})$ exposed larvae
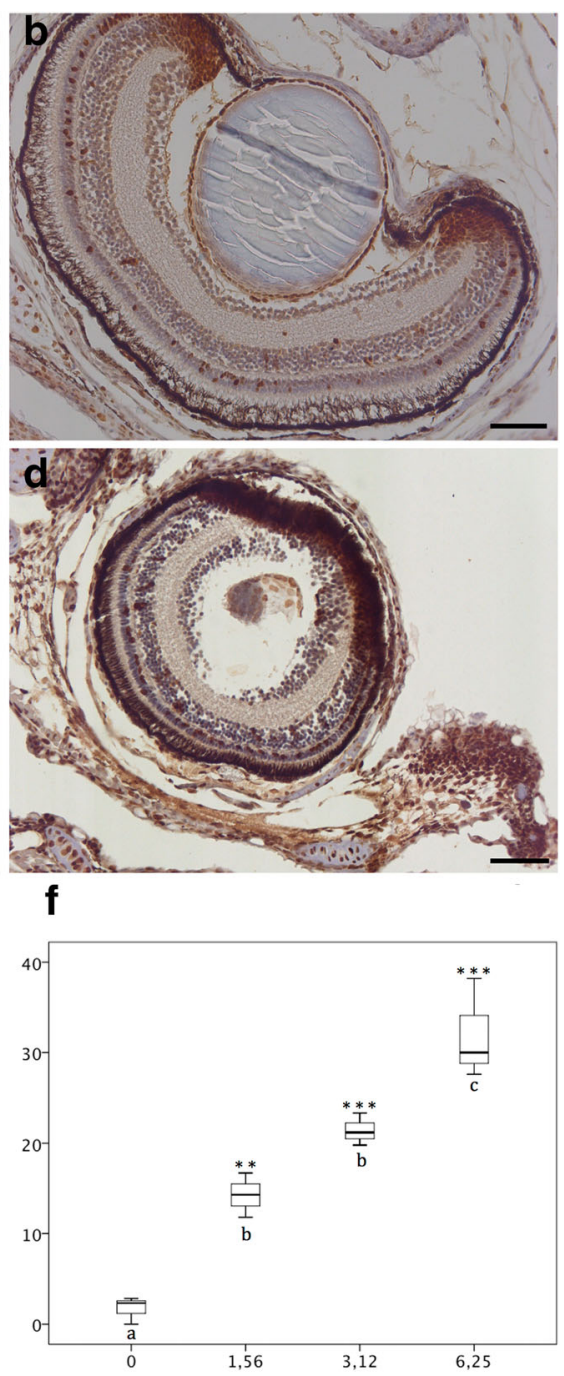

ONL of $30 \mathrm{dph}$ Malathion ( $\mu \mathrm{g} / \mathrm{L})$ exposed larvae

Fig. 9 (a to d) PCNA immunolocalisation in different retinal layer from controls (a) and 1.56 (b), 3.12 (c) and 6.25 (d) malathion exposed organisms. e and $\mathbf{f}$ PCNA index calculated in the inner and outher nuclear layers respectively at $30 \mathrm{dph}$ of malathion exposure. Note a significant increase of cell proliferation as malathion concentration increased in both inner (e) and outher ( $\mathbf{f})$ nuclear layers at $30 \mathrm{dph}$. Different letters indicate statistically significative differences between treatments. ${ }^{*}=P<0.05 ;{ }^{* *}=P<0.01 ;{ }^{* * *}=P<0.001$ ). Scalebar represents $100 \mu \mathrm{m}$

onwards, in those larvae exposed to malathion (at 1.56 and $3.12 \mu \mathrm{g} / \mathrm{L}$ ), and from $12 \mathrm{dph}$ onwards, with the highest concentration of malathion (at $6.25 \mu \mathrm{g} / \mathrm{L}$ ). At the end of the experimental period (at $30 \mathrm{dph}$ ), larvae exposed to 1.56 and $3.12 \mu \mathrm{g} / \mathrm{L}$ presented $I_{\mathrm{EM}}$ values of 3 and 2.12 respectively, whereas in those larvae exposed to the highest concentration of malathion (at $6.25 \mu \mathrm{g} / \mathrm{L}$ ) showed the lowest values of $I_{\mathrm{EM}}=0.44$. According to previous reports [34, 72], in the present study, exclusively the controls completed the eye migration at $30 \mathrm{dph}\left(I_{\mathrm{EM}}: 5\right)$. In different flatfish species, variable changes of the $I_{\mathrm{EM}}$ have been recorded in response to different stress conditions and nutritional and environmental factors. In this context, Hamre et al. [73], in the metamorphosis of the halibut indicated that the $I_{\mathrm{EM}}$ was affected by the composition of consumed preys. Sæle et al. [74] in the Senegalese sole, also observed differences in the eye migration index that depended on the quality of preys. On the other hand, Soffientino et al. [75] in larvae of the summer flounder exposed to contaminants (e.g., PCB-126) registered a delay of the metamorphic progress determined by a lower value of the $I_{\mathrm{EM}}$ and smaller fish size. Accordingly, in early lifestages of the Senegalese sole, a reduction of the growth patterns which is induced by the mañathion is clearly accompanied by a lower eye migration index and consequently with a delayed process of metamorphosis. 


\section{Thyroid disorders}

Thyroid hormonal disruptions induced by different xenobiotics, enclosing OP-pesticides, can influence directly the progress of metamorphosis $[9,13]$. In different fish species, it has been suggested that the inhibitory effect of OP insecticides, as the malathion, among other xenobiotics acting as endocrine thyroid disruptors, could be attributed to changes and alterations in developing thyroid follicles, deficient iodide trapping, and/or inhibition of the enzymes necessaries for synthesis of $\mathrm{T}_{4}$, and thus conversion of $\mathrm{T}_{4}$ to $\mathrm{T}_{3}$ hormones [9,76-78]. In comparison with the normal thyroid gland ontogeny and thyroidal hormonal patterns previously described on this flatfish species [31, 79, 80], among others, different ontogenetic and physiological damages, and thyroid disruptions were registered in malathion exposed $S$. senegalensis larvae, during metamorphic and post-metamorphic stages (at 13 and $30 \mathrm{dph}$ ): minor size and number of follicles, decreases in thyroid hormone production, detected by means of immunohistochemical procedures, and lower $\operatorname{Tr} \beta$ transcript expression levels. In parallel to these thyroid disruptions, significant delays or failures in the metamorphosis process, abnormal flatfish phenotypes, alterations and failure of eye migration (decreased $I_{\mathrm{EM}}$ ), as well as pigmentation and skeletal abnormalities have been registered in malathion exposed fish, and specially at the highest malathion concentration tested (at $6.25 \mu \mathrm{g} / \mathrm{L}$ ), during the metamorphosis process (13-30 dph).

As previously described, the size and height of the follicular epithelium of thyrocytes is a marker of the secretory activity of the thyroid gland $[79,81]$. The thyroid gland from controls is characterized by numerous and big follicles lined by cuboidal or columnar cells and can be classified as actively secreting gland whereas such as has been recorded in malathion exposed Senegalese sole specimens, those thyroid glands with scarce follicles lined by flattened epithelial cells, are classified as less active glands according to these last authors. These results were corroborated by immunohistochemistry in the controls, in which $\mathrm{T}_{3}$ and $\mathrm{T}_{4}$ immunostainings were strongly detected in cuboidal cells and colloid content from thyroid follicles, and in plasma content from vessels surrounding the follicles, indicating that the thyroid gland actively synthesize, accumulate and excrete hormones. Unlike, in malathion exposed fish, $\mathrm{T}_{3}$ and $\mathrm{T}_{4}$ immunoreactivities were scarcely and weakly located in the colloid content, but not in plasma, neither in follicle-surrounding epithelial cells. Similar results were reported in the catfish Heteropneus fossilis [82], and in Clarias batrachus [54, 83], in which the OP pesticide treatments induced a decline in thyroid hormone levels. In this context, Sinha et al. [83] reported that exposure to malathion appeared to decline the plasma $T_{3}$ levels and $\mathrm{T}_{3} / \mathrm{T}_{4}$ ratio, suggesting that this pesticide not only blocks the $T_{4}$ secretion, but also inhibits the thyroidal conversion of $\mathrm{T}_{4}$ into $\mathrm{T}_{3}$, by the action of deiodinases $1,2,3[23,31]$. Furthermore, at the cellular level in several target organs, the thyroid hormonal signalling is generally initiated by the interaction of the active hormone, $\mathrm{T}_{3}$, and binding to the thyroid receptors (TRs). Tr $\alpha$ is important for post-natal development, cardiac function, and regulation of deiodinases in cerebral cortex, while the $\operatorname{Tr} \beta$ mediates the regulation of the liver metabolism and thyroid hormones by a negative feedback through the HPT axis [22, 23]. Moreover, transcripts of $\operatorname{Tr} \beta$ are mainly expressed in the pituitary, liver and kidney, while Tr $\alpha$ should be ubiquitously expressed (Kim et al. 2015). In different flatfish species, there is a concomitant rise of both hormone levels $\left(\mathrm{T}_{3}, \mathrm{~T}_{4}\right)$ and thyroid receptors $(\operatorname{Tr} \alpha, \operatorname{Tr} \beta)$ during metamorphosis climax, and a subsequent decline toward metamorphic post-climax [22, 35]. Similar results were previously described in $S$ senegalensis development, with parallel expression patterns for both $\operatorname{Tr} \beta$ and $\mathrm{T}_{4}$ levels. Moreover, it was pointedout that $\operatorname{Tr} \beta$ transcription is up-regulated by THs that play a major role during the metamorphosis $[31,80]$. In the present study, the highest $\operatorname{Tr} \beta$ expression levels were reached at 13-20 dph and 20$30 \mathrm{dph}$ (metamorphosis and post-climax), such as it has been previously reported on this flatfish $[23,31,80]$. A significant down-regulation of the $\operatorname{Tr} \beta$ expression levels after malathion exposure was recorded from $13 \mathrm{dph}$ onwards coinciding with the onset of the metamorphosis phase (from $11 \mathrm{dph}$ onwards). Decreased $\operatorname{Tr} \beta$ transcript levels in malathion-exposed larvae occurred in parallel with a decrease of the content of THs, such as it has been detected by immunohistochemistry, in the present study. It has been pointed out that the malathion modulates thyroid receptors-mediated gene expression, not only directly by interacting with the TRs, but also by controlling plasmatic $\mathrm{T}_{3}$ levels [77].

\section{Skeletal alterations}

The baseline expression patterns of both OC and MGP, used as markers of bone and cartilage development respectively, as well as the immunohistochemical distribution of both proteins during the development and metamorphosis of the Senegalese sole, was previously reported by Gavaia et al. [36]. In the present study, the controls displayed low levels of the $O c$ mRNA transcripts, at early life stages (from 4 to $15 \mathrm{dph}$ ), and a significant up-regulation (increased $O c$ levels) was recorded from $15 \mathrm{dph}$ until the end of metamorphosis. Unlike, in malathion exposed metamorphosing and post-metamorphosed larvae and post-larvae, a strong reduction in the expression levels of the Oc mRNA transcripts was registered. These results were sustained by immunohistochemistry data, in which the osteocalcin protein-OC was located in skeletal tissues underwent calcification in the controls, whereas it was devoid of 
OC-immunoreactivity, in the malathion exposed fish. Because the osteoblasts express acetylcholinesterase (AChE), any OP-pesticide that target and disrupt cholinergic signaling pathways, as the malathion, may affect bone development and remodeling via their effects on osteoblasts by reducing its cholinesterase activity [84-86].

In the present study, malathion exposed larvae showed a precocious peak of expression of the Mgp mRNA at 11 $\mathrm{dph}$, that was restored to similar baseline levels that the controls at $13 \mathrm{dph}$, followed by a strong reduction of the Mgp transcript levels from $13 \mathrm{dph}$ onwards, in comparison with controls, until the end of the experiment. Similar results were obseved by immunohistochemistry, since malathion exposed larvae showed a visible reduction of the MGP immunostained areas. Considering the role of the MGP, as a physiological inhibitor of calcification, the effects of the precocious expression of the Mgp mRNA on bone development and mineralization could be synergistic to the parallel decrease of the expression levels of the $O c$ mRNA transcripts, in those malathion exposed specimens, conducting to a delay in skeletal development. Because the MGP is secreted by chondrocytes and vascular smooth- muscle cells (vsmc), any compound that disrupt activity of these cells, like the malathion, may affect levels of MGP proteins, and therefore it will affect to bone development [85].

On the other hand, it is also assumed that, in fish species, the normal bone development can be disrupted by deficiences or by increases of thyroid hormonal levels, depending on stages of larval ontogeny and timing of transition into juveniles [22, 87]. In this sense, and for corroborating the influence of the thyroidal signaling pathways in the skeletal development, a close relation-ship between serum concentration of $\mathrm{OC}$ and thyroid status has been reported [88-90]. Another evidence concerning the role of thyroid in bone development is the fact that TRs which recognize specific response-elements in the promoter region of target genes, are present in the osteoblasts [91]. Therefore, this fact regulates the expression of non-collagenous proteins, like the osteocalcin-OC. Additionally, in a study regarding the role of thyroid hormones in tissue calcification, Sato et al. [92] concluded that the presence of $\mathrm{T}_{3}$ (3',3,5-triiodo-L-thyronine) regulated the Mgp gene expression patterns in vascular smooth muscle cells. Furthermore, it has been reported that thyroid hormones regulate the expression of several genes implicated in bone formation, such as collagenase- 3 , gelatinase- 3 and osteocalcin in osteoblasts-like cells culture [93].

In addition, it can be suggested that the OP malathion affects bone development and ossification processes by a direct disruption of the target cells (osteoblasts and mesenchymal stem derived cells-MSCs) that secrete these Gla-containing proteins (OC and MGP) or indirectly by affecting the thyroidal signaling pathways that regulates the expression of both the Oc or Mgp genes. In any case, both mechanisms can conduce to abnormal phenotypes, since significant delays in bone development and ossification processes were evidenced, showing many cartilage structures in advanced stages of larval development (at $6.25 \mu \mathrm{g}$ malathion/L, at $30 \mathrm{dph}$ ), when bone structures should be ossified. There are numerous reports that support the role of the ossification index (performed by means of AA/AR technique) as a good biomarker of skeletal development and malformations [94-98]. In the present study, when skeletal phenotypes are analysed, it can be observed a different degree of mineralization, when comparing controls and malathion exposed specimens, in particular in certain structures from those specimens exposed to the highest malathion concentrations (at $6.25 \mu \mathrm{g} / \mathrm{L}$ ). In fact, in controls at $30 \mathrm{dph}$, it was recorded an extended alizarin- red staining located in lower and upper jaws, cranial bones, sphenoid, ceratobranchials, cleithrum, mesethmoid, lateral ethmoid, vertebral centra, neural and haemal spines, whereas in the malathion exposed fish, cranial bones, dorsal and ventral pherigophores, fin rays or sphenoid were devoid of AR staining, suggesting that skeletogenesis was arrested, by effect of the OP malathion.

\section{Eye development and disruptions}

Eye development in the flatfish, Solea senegalensis is a remarkably fast process that gives to fish, the visual capabilities for prey capture, and feed needs, at the early larval phase of the ontogeny [37], such as it has been reported in many other fish species, and in all vertebrates $[22,23]$. Thyroid system is a crucial key for eye development in vertebrates, and therefore, any disruption in the thyroid axis might affect the eye morphology of developing flatfish species [23]. As a consequence, fish larvae exposed to thyroid disruptors, as the OP malathion, become particularly vulnerable, because vision and other sensory organs are impaired particularly during the metamorphosis process [99]. In the present study, at the beginning of the metamorphosis in the controls, both eyes are well developed, differentiated, and under maturation processes, with all structurally formed retinal layers and cell types (pigment epithelium, nuclears, plexiforms, ganglion cell layers among others), and showing different functional retinal neuromarkers, such as it was previously reported on this flatfish species $[37,100]$. On the other hand, malathion exposed specimens displayed, at $30 \mathrm{dph}$, a decreased developmental pattern, in both the eye size and thickness of the retinal pigment epithelium (RPE). Thus, the eye-size in terms of longest eye diameter was reduced from an average of $0,48 \mathrm{~mm}$ for controls, to $0,24 \mathrm{~mm}$ for $6.25 \mu \mathrm{g} / \mathrm{L}$ malathion exposed fish. Similar results were reported by Cook et al. [63] in juveniles of the zebrafish exposed to 
malathion, in which a significantly reduction of the eye-size was detected. However, the relative eye-size corrected for total length significantly increased in a dose-dependent way, at 20 and $30 \mathrm{dph}$, suggesting that the observed reduction in eye-size likely could be an overall developmental delay of the different organs-systems, rather than an specific and particular effect on the eye development provoked by the malathion [101]. In the present study, and parallelly to a decrease of the eye-size, in malathion exposed specimens, an increase of the PCNA index, in both the ONL and INL retinal layers, in a dose-dependent manner, was detected. As suggested by Negishi et al. [102] in a study in goldfish treated with neurotoxins, a cell damage in the retinal cells induced by toxins, provoked increases in the number of PCNA-positive cells, which could indicate a cell over-production or increased cell-proliferation rates for repairing of retinal toxicant injury.

In the Senegalese sole, parallely to eye development and differentiation, the migration of the left eye occurs during the metamorphosis. Several variants of the eye migration and adaptive behaviors in response to malathion treatments have been detected in the present study at $30 \mathrm{dph}$ : (1).- Bilateral symmetry with upright swimming and planktonic behaviors in the majority of the sampled fish (up to 75\%) exposed to $6.25 \mu \mathrm{g} / \mathrm{L}$; (2).- Bilaterally symmetric eyes with lateralized behaviors with their left sides on the bottom in half of Senegalese sole larvae exposed to $3.12 \mu \mathrm{g} / \mathrm{L}$ (up to $40 \%$ ) and in some of the larva exposed to $1.56 \mu \mathrm{g} / \mathrm{L}$ (up to $15 \%$ ) and (3).- Incomplete eye migration with one of the eyes partially repositioned to the other side in some of the exposed to $1.56 \mu \mathrm{g} / \mathrm{L}$ (up to $35 \%$ ) and finally (4).- Complete eye migration such as it has been observed in all sampled controls and in a half of the fish exposed to $1.56 \mu \mathrm{g} / \mathrm{L}$ (up to $50 \%$ ). Although it was previously pointed out that lateralized behaviours are adaptative responses for changing the eye position [103], Schreiber [104] in other study in southern flounder (Paralichthys lethostigma), in pre-metamorphic larvae treated with thyroid hormones concluded that although lateralized behaviours and eye migration occurred, in response to thyroid hormones during metamorphosis, both processes are independent to each other [104]. Further, these authors suggested that the development of lateralized behaviors was a result of a vestibular response to thyroid hormones rather than an adaptive response to eye translocation. In this sense, morphological asymmetries of the otoliths as well as of the utricles and saccules from the inner ear, have been detected in adult flatfish [105-107]. In flatfish species, the process of eye migration starts with an asymmetrical growth of neurocraneal bones, the frontal bones and paraethmoids, initially located in symmetrical position between the eyes. The movement of this bone structure exerts a stretch on the fibroblast in the connective tissues found between the moving structures and one eye migrates to the other side of the body [108]. However, there could occur a physical blockage of eye extension if that asymmetrical ossification of cranial bone structures is disrupted [109]. Because bone ossification and remodeling are thyroid-driven processes, exposure to any contaminant that can affect the thyroid axis can also alter bone development and, consequently, the appropriate eye migration [110], such as was detected in Senegalese sole exposed to the OP-malathion $(6.25 \mu \mathrm{g} / \mathrm{l}$, at $30 \mathrm{dph})$.

\section{Conclusion}

In conclusion this study confirms that the subacute exposure to environmentally relevant sublethal concentrations of the OP malathion particularly during the Senegalese sole metamorphosis significantly altered the ontogenetic developmental events and growth patterns, by a direct toxic effect over target cells, organs and tissues (i.e. thyroid, eye, skeleton). Additionally, all of the induced disruptions may affect to the functionality of these organs and tissues, and/or indirectly altering the thyroid signaling cascade, as for instance, to block hormonal synthesis, secretions, and thyroidal homeostasis. Accordingly, all these potential umbalances may lead to noticeable metamorphic failures, through several disruptive thyroidal processes, which may arrest the onsent and advancement of the most important ontogenetic metamorphosing events, such as the migration of the eye, skeletal development and bone remodeling, and the acquisition of benthic life and settling behaviors.

\section{Methods}

\section{Larval rearing and experimental assays}

Newly hatched S. senegalensis larvae (provided by the IFAPA-El Toruño; Regional Government of Andalusia, Spain) were reared at the ICMAN-CSIC (Puerto Real, Cadiz, Spain). Larvae ( $n=60$ per L) were distributed into fifteen $16 \mathrm{~L}$ cylindro-conical tanks (control+control/carrier+ 3 malation concentrations $\mathrm{x}$ triplicate), and used for different experimental assays. Water temperature was maintained at $20 \pm 0.4^{\circ} \mathrm{C}$, salinity $32-38 \mathrm{gL}^{-1}$, and dissolved oxygen $85-100 \%$. Photoperiod was maintained at $12 \mathrm{~h}$ light: $12 \mathrm{~h}$ dark and mild aireation was provided. Larvae were fed rotifers from 3 to 9 days post hatching (dph) at a density of 15 organisms per $\mathrm{ml}$ and artemia nauplii from $6 \mathrm{dph}$ at a initial density of 1 organism per ml. Artemia density was gradually increased, becoming the only prey added from $5 \mathrm{dph}$ onwards, according to previous studies [79].

Recent results performed in S. senegalensis larvae exposed to malathion revealed that the toxic-sublethal 
concentrations of this OP insecticide ranged between 1.56 and $6.25 \mu \mathrm{gL}^{-1}$ [55]. Larvae from $4 \mathrm{dph}$ and during the first month of life (on day 30 ) were exposed to malathion (Sigma Aldrich Chemical Co, St Louis) under semistatic-renewal toxicity tests $(50 \%$ of renewal each $24 \mathrm{~h})$. Three different nominal concentrations of malathion $\left(1.56,3.12,6.25 \mu \mathrm{gL}^{-1}\right)$ were tested. All experimental treatments and control received the same carrier solvent $(0.01 \%$ acetone, maximum acceptable limit for solvent with no observable effect, according to OECD guidelines [111, 112]. A control group without solvent was also handled in parallel with the experimental assay. Three replicates were performed for each test (control and treatments).

All experimental designs and fish handling were performed in accordance with the European Directive and followed the Spanish normative (RD 1201/2005) and procedures of animal welfare (ICMAN-CSIC facilities; REGA-ES110280000311). The experimental procedure (Proyect AGL2010-15951) was approved by the Spanish National Research Council (CSIC) Ethical Committee, and Ethical Committee for Animal Welfare of ICMAN-CSIC.

All experiments were performed with Senegalese sole larvae from $4 \mathrm{dph}$ onwards, in order to avoid the high natural mortality, that is very common, during the endogenous feeding phase of this flatfish species.

\section{Biometric parameters}

Standard length (SL) and dry weight (DW) were measured in larvae at 5, 10, 20 and $30 \mathrm{dph}$. Thirty larvae from each experimental tank were randomly sampled and euthanized with an overdose of tricaine methane sulphonate (MS-222, Sigma Aldrich). SL was measured using a stereomicroscope equipped with an eye-piece with a metric scale. DW calculation was performed according to Fernández-Díaz et al. [34] by rinsing larvae with distilled water to remove salt and then oven-drying at $60^{\circ} \mathrm{C}$ for $24 \mathrm{~h}$. Samples were weighed with an analytic microbalance.

The eye migration index $\left(I_{\mathrm{EM}}=\Sigma(\%\right.$ fish in each stage $\mathrm{x}$ stage)/100) is ussually used in the Senegalese sole development, as a valuable measurement tool for evaluating the metamorphosis advancement. In our experiment, eye migration was assessed at 6, 12, 13, 15, 20 and 30 dph (15 larvae per replicate) according to Villalta et al. [72]. Data are presented as the relative number (percentage) of larvae at each stage of development, i.e. at S0, S1, S2, S3a, S3b, S4 (to see [113]), and evaluated at the same sampling time.

\section{Histological procedures}

For histological purposes, a RNAse free procedure was used according to previous studies [114]. At the end of the experimental period (on day 30), about ten to fifteen larvae per each treatment (3 independent replicates, respectively) were sampled and fixed with $4 \%$ freshly prepared paraformaldehyde (PFA) in diethylpyrocarbonate-(DEPC)-treated phosphate buffered saline for $24 \mathrm{~h}$. Afterwards, samples were stored in methanol at $-20^{\circ} \mathrm{C}$ and then processed according to Ortiz-Delgado et al. $[79,114]$ Serial sagittal and coronal sections $(5-6 \mu \mathrm{M}$ thick) were used for the different histological approaches.

\section{Eye development}

Serial coronal sections $(=5 \mu \mathrm{M})$ from both control and exposed larvae were stained with Haematoxylin-Eosin (HE), and analysed using a light microscope (BX41 Olympus light microscope equipped with an Olympus digital camera (c3030)). Eye-size was measured as the longest diameter of the eye. Relative eye-length, was calculated as the ratio of eye length over total length expressed as apercentage. Differences in thickness of the different retinal layers (PL: pigmentary layer; ONL: outer nuclear layer; OPL: outer plexiform layer; INL: inner nuclear layer; IPL: inner plexiform layer; GCL: ganglion cell layer) in response to the OP malathion treatments were also analysed.

To measure cell proliferation index, in the different retinal layers, immunohistochemical approaches were assessed by using as primary antibody, anti-proliferating cell nuclear antigen/anti-PCNA (Santa Cruz Biotechnology) such as was described by Bakke-McKellep et al. [115]. Quantification of cell proliferation was conducted according to Sirri et al. [116]. From each histological section, several microphotographs were performed from various retinal areas, with different magnifications. Strongly PCNA-immunoreactive (PCNA-ir) cells were counted per area $\left(0.1 \times 10^{4} \mu \mathrm{m}^{2}\right)$, in the outer and inner nuclear layers (ONL and INL respectively) except for retinal margins, where PCNA-ir cells were densely packed. Data from different retinal regions were used to calculate PCNA index according to Lee et al. [117] as follows:

PCNA index $=\frac{\text { Number of PCNA }- \text { positive nuclei }}{\text { Number of PCNA }- \text { positive }+ \text { negative nuclei }} \times 100$.

\section{Thyroid gland development}

The development of the thyroid gland (number and size of thyroidal follicles) and the immunohistochemical detection of THs, thyroxin $\left(\mathrm{T}_{4}\right)$ and triiodothyronine $\left(\mathrm{T}_{3}\right)$ were evaluated on histological sections of larvae and post-larvae at 13, 15 and $30 \mathrm{dph}(n=3$ specimens per experimental condition x triplicate: $n=9$ ) according to Ortiz-Delgado et al. [79] by using monoclonal antibodies (Cat. 10-T35A M94210-515 
and Cat. 10-T30B M94207-3010 from Fitzgerald (USA), respectively) previously validated for this species.

\section{Skeletal staining analysis}

To evaluate the impact of different malathion concentrations on the ossification of the skeleton, 20 larvae per each experimental tank were randomly sampled at the end of experimental period (at 30 days), fixed in $4 \%$ formaldehyde at $\mathrm{pH}=7.0$ with $0.1 \mathrm{M}$ phosphate buffer. Fish were stained with Alcian Blue ( $\mathrm{pH}: 2.5)$ and Alizarin Red to detect cartilaginous and bony tissues, respectively [118]. Skeletal structures were identified according to Gavaia et al. [118] and Wagemans and Vandewalle [119].

The differences in the distribution patterns of osteocalcin-OC (as a marker of calcified bone tissue) and matrix Gla protein-MGP (a calcification inhibitor of soft tissues), as response to malathion treatments, were determined by immunohistochemical approaches [120]. Briefly, serial histological sections were incubated overnight with primary antibodies at suitable dilutions (1500 for OC, 1:250 for MGP). After incubation, sections were washed 3 times for 30 min each in PTW and incubated for $1 \mathrm{~h}$ with secondary antibody (goat anti rabbit IgG peroxidase conjugated at 1:1000 (Sigma, St Louis, MO, USA)). Peroxidase immunodetection was achieved by staining with $3,3^{\prime}$-diaminobenzidine/DAB as chromogenic substrate, in Tris-Hcl $0.05 \mathrm{M}$, at $\mathrm{pH}$ : 7.6 containing $0.05 \%$ hydrogen peroxide. To confirm the specificity of antibodies, negative controls were performed by replacing the primary antibody with pre-immune serum or BSA and by omission of primary or secondary antibodies.

\section{RNA isolation and CDNA synthesis}

Pools of larvae of different ages (from 4, 11, 13, 15, 20 and $30 \mathrm{dph}$ ) were collected, washed with DEPC water, frozen in liquid nitrogen and stored at $-80^{\circ} \mathrm{C}$ until RNA extraction. Total RNA was isolated from $40 \mathrm{mg}$ of pooled larvae using NucleoSpin ${ }^{\circ}$ NA II kit (Macherey-Nagel, Düren, Germany) coupling with Lysing Matrix D (Q-BioGene) for $40 \mathrm{~s}$ at speed setting 6 in the Fastprep FG120 instrument (Bio101), according to the manufacturer's instructions. In all cases, total RNA was treated twice with DNase I using the RNase-Free DNase kit (Qiagen) for 30 min in order to avoid amplification of contaminated genomic DNA. RNA sample quality was checked using Experion (Bio-Rad) and quantification was performed spectrophotometrically. Total RNA $(1 \mu \mathrm{g})$ from each sample was reverse-transcribed using the iScript ${ }^{\mathrm{Tw}} \mathrm{cDNA}$ Synthesis kit (Bio-Rad). Lack of genomic DNA contamination was confirmed by PCR amplification of RNA samples in the absence of cDNA synthesis.

\section{Real-time q-PCR}

Real-time analysis was carried out on the iCycler (Bio-Rad). Reactions were accomplished in a $25 \mu \mathrm{l}$ volume containing cDNA generated from $10 \mathrm{ng}$ of original RNA template, $400 \mathrm{nM}$ each of specific forward and reverse primers, and $5 \mu \mathrm{l}$ of SensiFAST SYBR No-ROX (Bioline). Matching oligonucleotide primers were designed for OcandMgp genes using the Oligo v6.89 software (Medprobe) and sequence database GeneBank or SoleaDB (Table 2). To $\operatorname{Tr} \beta$ gene, primers SseTrßF3 y SseTRrß4 were used [80]. Amplification of cDNA fragments encoding target genes was verified in previous assays by direct sequencing of PCR products obtained with the same reaction conditions employed in real-time PCR. The real-time amplification protocol used was as follows: initial $7 \mathrm{~min}$ denaturation and enzyme activation at $95^{\circ} \mathrm{C}, 40$ cycles of $95^{\circ} \mathrm{C}$ for $15 \mathrm{~s}$, and $68^{\circ} \mathrm{C}$ for $30 \mathrm{~s}$. Each assay was done in duplicate. For normalization of cDNA loading, all samples were run in parallel using ubiquitin as housekeeping gene with primers SseUB1 and SseUB2 (Table 2) according to Infante et al. [121]. To estimate efficiencies, a standard curve was generated for each primer pair based on known quantities of cDNA (10-fold serial dilutions corresponding to cDNA transcribed from 100 to $0.01 \mathrm{ng}$ of total RNA). All calibration curves exhibited correlation coefficients higher than 0.98 , and the corresponding real-time PCR efficiencies were around 2.1-2.2 for both all genes. Relative mRNA expression was determined using the $2^{-(\Delta \Delta \mathrm{Ct})}$ method [122]. Results were expressed as mean \pm SEM. Statistical

Table 2 Primers used for quantification of $\operatorname{Tr} \beta$, Oc and Mgp mRNA levels in S. senegalensis

\begin{tabular}{|c|c|c|c|c|}
\hline Gene target & Primers & Sequence $\left(5^{\prime}-3^{\prime}\right)$ & Base origin & Size $(b p)$ \\
\hline Sse UB & SseUB1 & AGCTGGCCCAGAAATATAACTGCGACA & 256 & 93 \\
\hline (AB291588.1) & SseUB2 & ACTTCTTCTTGCGGCAGTTGACAGCAC & 348 & \\
\hline SseTr $\beta$ & SseTrßF3 & AAACAGAAGCGGAAGTTCCTGAGTGCAG & 493 & 100 \\
\hline (GU946412) & SseTrßF4 & CTITGTTCCTTCAGGTGTGTTTGCCATC & 592 & \\
\hline Sse MGP & SseMGP1 & GGTGCCCGGAGTCAGCCACA & 88 & 113 \\
\hline (AY113679) & SseMGP2 & AGCTGGTCTCTGGGGTCTCAGGTT & 200 & \\
\hline Sse OC & SseOC1 & GGTTCTCTGCTCCCTGGCCGTCCTCT & 21 & 115 \\
\hline (AY823525) & SseOC2 & GACGCCTGCTCCTGCTCCACAAACAA & 135 & \\
\hline
\end{tabular}


analyses were carried out using the non-parametric Mann-Whitney $U$ test employing the InsStat v3.0 software. Significance was accepted for $P<0.05$.

\section{In situ hibridization}

To study the localization of $\operatorname{Tr} \beta$, Oc and Mgp gene expression patterns in different cell- types and tissues of the Senegalese sole, in situ hybridization was performed on histological sections of controls and malathion exposed fish. To synthesize correspondent probes, different PCR fragments around $93-135 \mathrm{bp}$ belonging toTRß, OC and MGP cDNA, were amplified using specific primers (Table 2) and cloned with TOPO-TA Cloning kit (Invitrogen). Sense and anti-sense probes were synthesized using the DIG RNA labeling kit $\left(\mathrm{SP}_{6} / \mathrm{T}_{7}\right)$ (Roche diagnostics, Indianapolis, USA) according to the manufacturer's instructions. Specificity to these probes was confirmed by northern blot analysis. In situ hybridization protocols on histological sections from controls and malathion exposed Senegalese sole specimens were performed such as it is described by Ortiz-Delgado et al. [114]. Briefly, sections were rehydratedand permeabilised for $15 \mathrm{~min}$ in $10 \mu \mathrm{g} / \mathrm{mL}$ proteinase $\mathrm{K}$ in phosphatebuffered saline with Tween 20 (PBST: $137 \mathrm{mM} \mathrm{NaCl}, 2.7 \mathrm{mM} \mathrm{KCl,1.8} \mathrm{mM} \mathrm{KH}_{2} \mathrm{PO}_{4}$, $10 \mathrm{mM} \mathrm{Na} \mathrm{NaO}_{4}, 0.1 \%$ Tween-20) at $37^{\circ} \mathrm{C}$. After post-fixation in $4 \%$ paraformaldehyde-PBST for 30 min, sections were incubated for $2 \times 15 \mathrm{~min}$ in PBST containing $0.1 \%$ active DEPC, and equilibrated for 15 min in PBST. The histological sections were then pre-hybridised for $2 \mathrm{~h}$ at $56^{\circ} \mathrm{C}$ in the hybridization mix, and later, they were hybridised with the sense or antisense probes at $56^{\circ} \mathrm{C}$ overnight in a humidified chamber. After incubation, the sections were washed three times in $2 \mathrm{x}$ SSC at $52^{\circ} \mathrm{C}$ for $30 \mathrm{~min}$, later they were washed twice at $52^{\circ}$ C with $1.4 x$ SSC/0.6\% CHAPS (3-[3-cholamidopropyl)-dimethylamino]1-propanesulfonate, and once with 1:1 PTW: maleic acid buffer (0.1 M maleic acid, $0.15 \mathrm{M} \mathrm{NaCl}, \mathrm{pH} 7.5)$. Detection of the hybridized probe was carried out using alkaline phosphatase-coupled anti-digoxigenin antibody, and the hybridization signals were detected by NBT/BCIP systems according to the manufacturer's instructions (Roche), adding $5 \mathrm{mM}$ levamisole to neutralize endogenous alkaline phosphatase. The controls included hybridization with sense probes, RNase treatments before hybridization and absence of antisense RNA probe/anti-DIG antibody in the incubation medium.

\section{Statistical analysis}

Comparison between groups were made by using one-way analysis of variance (ANOVA). Normality was checked using the Shapiro-Wilk's test and the homogeneity of variances with the Levene's test. Tukey's post hoc test was used for identification of the statistically distinct groups.
The computer program InStat v3.0. vas used to perform the analyses. Differences were considered statistically significant at $p<0.05$. For statistical evaluation and graphical representations, control and solvent-carrier control were pooled, as they did not differ significantly with regard to the different recorded measurements.

The assessment for immunohistochemical results was performed independently by three observers, which analysed the same histological samples. From each sample, three histological slides of controls and of each experimental assay $(1.56,3.12$ and $6.25 \mu \mathrm{g} / \mathrm{L}$ ) were analysed from $4 \mathrm{dph}$ onwards.

\section{Abbreviations \\ AA-AR: Alcian blue-alizarin red; AChE: Acetylcholinesterase.; DW: Dry weigh; ECDs: Endocrine disrupting chemicals; GCL: Ganglion cell layer; \\ HPT: Hypothalamus-pituitary-thyroid axis; IEM: Index of eye migration; INL: Inner nuclear layer; IPL: Inner plexiform layer; LC 50 : Lethal concentration 50\%; LOEC: Lowest observed effect concentration; MGP: Matrix-Gla-protein; NOEC: No observed effect concentration; OC: Osteocalcin; ONL: Outer nuclear layer; OP: Organophosphate pesticide; OPL: Outer plexiform layer; PCNA: Proliferating cell nuclear antigen; PL: Pigmentary layer; THs: Thyroid hormones; TL: Total length; TR: Thyroid receptor}

\section{Acknowledgments}

The authors are grateful to M. Carmen Carmona and Juan Canales and J. Antonio Miquel for their invaluable technical assistance in this work.

\section{Funding}

This study was supported by Ministry of Science and Innovation MICIIN (Project AGL2010-15951) of the Spanish government.

\section{Availability of data and materials}

All relevant data are within this paper. Original data are available from the corresponding author (juanbosco.ortiz@icman.csic.es) on reasonable request.

\section{Author's contributions}

JBOD and CS, study conception, participation in the experimental design, analysis of results and manuscript writing; VF performing experimental technical part (molecular tools) and statistical analysis and manuscript revision. All authors have participated actively in the study and approved the final manuscript.

\section{Ethics approval and consent to participate}

All experimental designs and fish handling were performed in accordance with the European Directive and followed the Spanish normative (RD 1201/ 2005) and procedures of animal welfare (ICMAN-CSIC facilities; REGAES110280000311). The experimental procedure (Proyect AGL2010-15951) was approved by the Spanish National Research Council (CSIC) Ethical Committee, and Ethical Committee for Animal Welfare of ICMAN-CSIC.

\section{Consent for publication}

Not applicable.

\section{Competing interests}

The authors declare that they have no competing interests.

\section{Publisher's Note}

Springer Nature remains neutral with regard to jurisdictional claims in published maps and institutional affiliations.

\section{Author details}

${ }^{1}$ Instituto de Ciencias Marinas de Andalucía-ICMAN, CSIC Campus Universitario Río San Pedro, 11510 Puerto Real, Cádiz, Spain. ${ }^{2}$ IFAPA, Centro el Toruño, Junta de Andalucía, Camino Tiro de Pichón s/n, 11500 El Puerto de Santa María, Cádiz, Spain. 


\section{Received: 19 September 2018 Accepted: 16 January 2019}

\section{Published online: 11 February 2019}

\section{References}

1. Nascimento RA, Almeida M, Escobar NCF, Ferreira SLC, Mortatti J, Queiroz AFS. Sources and distribution of polycyclic aromatic hydrocarbons (PAHs) and organic matter in surface sediments of an estuary under petroleum activity influence, Todos os Santos Bay, Brazil. Mar Pollut Bull. 2017;1 19:223-30.

2. Lal B. Malathion-induced endocrine disruption leads retardation in fish growth. Res Environ Life Sci. 2012;5(4):223-9.

3. Deka S, Mahanta R. Malathion toxicity on fish-a review. Int J Curr Res. 2016 8(12):44120-8.

4. Nugegoda D, Kibria G. Effects of environmental chemicals on fish thyroid function: implications for fisheries and aquaculture in Australia. Gen Comp Endocrinol. 2017:244:40-53.

5. Liess M, Brown C, Dohmen P, Duquesne S, Heimbach F, Kreuger J. Effects of pesticides in the field-EPIF. Brussels, Belgium: SETAC Press; 2005.

6. Singh SK, Tripathi PK, Yadav RP, Singh D, Singh A. Toxicity of malathion and carbaryl pesticides: effects on some biochemical profiles of the freshwater fish Colisa fasciatus. Bull Environ Contam Toxicol. 2003;72(3):592-9.

7. Lal B, Sarang MK, Kumar P. Malathion exposure induces the endocrine disruption and growth retardation in the catfish, Clarias batrachus (Linn.). Gen Comp Endocr. 2013;181:139-45.

8. Sabra FS, Mehana SD. Pesticides toxicity in fish with particular reference to insecticides. Asian J Agric Food Sci. 2015;3(1):40-60.

9. Brown SB, Adams BA, Cyr DG, Eales JG. Contaminant effects on the teleost fish thyroid. Environ Toxicol Chem. 2004;23:1680-701.

10. Scott GR, Sloman KA. The effects of environmental pollutants on complex fish behaviour: integrating behavioural and physiological indicators of toxicity. Aquat Toxicol. 2004;68:369-92.

11. Mnif W, Pillon A, Balaguer P, Bartegi A. Endocrine xenoestrogenics disrupters: molecular mechanisms and detection methods. Therapie. 2007; 62(5):369-86.

12. Mnif W, Hassine AlH, Bouaziz A, Bartegi A, Thomas O, Roig B. Effect of endocrine disruptor pesticides: a review. Int J Environ Res Public Heal. 2011; 8:2265-303.

13. Schreiber M. Flatfish: an asymmetric perspective on metamorphosis. Curr Top Dev Biol. 2013;103:167-94.

14. Weis JS. Delayed behavioral effects of early life toxicant exposures in aquatic biota. Toxics. 2014;2:165-87.

15. Baumann L, Ros A, Rehberger K, Neuhauss SCF, Segner H. Thyroid disruption in zebrafish (Danio rerio) larvae: different molecular response patterns lead to impaired eye development and visual functions. Aquat Toxicol. 2016:172:44-55.

16. Thienpont B, Tingaud-Sequeira A, Prats E, Barata C, Babin PJ, Raldúa D. Zebrafish eleutheroembryos provide a suitable vertebrate model for screening chemicals that impair thyroid hormone synthesis. Environ Sci Technol. 2011:45:7525-32.

17. Boas M, Feldt-Rasmussen U, Main KM. Thyroid effects of endocrine disrupting chemicals. Mol Cell Endocrinol. 2012;355(2):240-8.

18. Grant BF, Mehrle PM. Pesticide effects on fish endocrine systems. In: Progress in sport fishery research Bull Sport Fish Res 1970; 106: 318

19. Pandey A, George K, Mohamed M. Effect of DDT on the thyroid gland of the mullet Liza parsia. J Mar Biol Assoc India. 1995;37:287-90.

20. Bhattacharya S, Kumar D, Das RH. Inhibition of the thyroid hormone formation by endrin in the head kidney preparation of a teleost, Anabas testudineus (Bonch). Indian J Exp Biol. 1978;16:1310-2.

21. Brown DD, Cai L. Amphibian metamorphosis. Dev Biol. 2007;306(1):20-33.

22. Power DM, Einarsdóttir IE, Pittman K, Sweeney GE, Hildahl J, Campinho MA Silva N, Sle $\varnothing$, Galay-Burgos M, Smaradóttir H, Björnsson BT. The molecular and endocrine basis of flatfish metamorphosis. Rev Fish Sci. 2008;16(1):93-109.

23. Darras VM, Houbrechts AM, Van Herck SLJ. Intracellular thyroid hormone metabolism as a local regulator of nuclear thyroid hormone receptormediated impact on vertebrate development. Biochim Biophys Acta. 2015; 1849(2):130-41.

24. Evans BI, Fernald RD. Metamorphosis and fish vision. J Neurobiol. 1990;21(7): 1037-52.

25. Yamano K, Miwa S, Obinata T, Inui Y. Thyroid hormone regulates developmental changes in muscle during flounder metamorphosis. Gen Comp Endocrinol. 1991;81(3):464-72.
26. Yamano K, Takano-Ohmuro H, Obinata T, Inui Y. Effect of thyroid hormone on developmental transition of myosin light chains during flounder metamorphosis. Gen Comp Endocrinol. 1994;93(3):321-6.

27. Matsumoto J, Sekai T. Assymetric pigmentation and pigment disorders in Pleuronectiformes (flounders). Pigment Cell Res. 1992;2:275-82.

28. Miwa S, Yamano K, Inui Y. Thyroid hormone stimulates gastric development in flounder larvae during metamorphosis. J Exp Zool. 1992;261(4):424-30.

29. Alves RN, Gomes AS, Stueber K, Tine M, Thorne MAS, Smáradóttir H, Reinhard R, Clark MS, Rønnestad I, Power DM. The transcriptome of metamorphosing flatfish. BMC Genomics. 2016;17:413.

30. Schnitzler JG, Klaren PHM, Mariavelle E, Das K. The thyroid gland and thyroid hormones in sheepshead minnow (Cyprinodon variegatus) during early development and metamorphosis. Fish Physiol Biochem. 2016a;42: 607-16.

31. Sarasquete C, Úbeda-Manzanaro M, Ortiz-Delgado JB. Effects of the soya isoflavone genistein in early life stages of the Senegalese sole, Solea senegalensis: thyroid, estrogenic and metabolic biomarkers. Gen Comp Endocrinol. 2017;250:136-51.

32. Blanton ML, Specker JL. The hypothalamic-pituitary-thyroid (HPT) axis in fish and its role in fish development and reproduction. Crit Rev Toxicol. 2007; 37(1-2):97-115.

33. Dinis MT, Ribeiro L, Soares F, Sarasquete C. A review on the cultivation potential of Solea senegalensis in Spain and in Portugal. Aquaculture. 1999; 176:27-38.

34. Fernández-Díaz C, Yúfera M, Cañavate JP, Moyano FJ, Alarcón FJ, Díaz M. Growth and physiological changes during metamorphosis of Senegal sole reared in the laboratory. J Fish Biol. 2001;58:1086-97.

35. Power DM, Llewellyn L, Faustino M, Nowell MA, Björnsson BT, Einarsdottir IE, Canario AVM, Sweeney GE. Thyroid hormones in growth and development of fish. Comp Biochem Phys C. 2001;130:447-59.

36. Gavaia PJ, Simes DC, Ortiz-Delgado JB, Viegas CSB, Pinto JP, Kelsh RN, Sarasquete MC, Cancela ML. Osteocalcin and matrix Gla protein in zebrafish (Danio rerio) and Senegal sole (Solea senegalensis): comparative gene and protein expression during larval development through adulthood. Gene Expr Patt. 2006;6:637-52

37. Padrós F, Villalta M, Gisbert E, Estévez A. Morphological and histological study of larval development of the Senegal sole Solea senegalensis: an integrative study. J Fish Biol. 2011;79(1):3-32.

38. Bohnsack BL, Kahana A. Thyroid hormone and retinoic acid interact to regulate zebrafish craniofacial neural crest development. Dev Biol. 2013;373:300-9.

39. Bertrand S, Thisse B, Tavares R, Sachs L, Chaumot A. Unexpected novel relational links uncovered by extensive developmental profiling of nuclear receptor expression. PLoS Genet. 2007;3(11):e188.

40. Suzuki SC, Bleckert A, Williams PR, Takechi M, Kawamura S, Wong ROL. Cone photoreceptor types in zebrafish are generated by symmetric terminal divisions of dedicated precursors. Proc Natl Acad Sci U S A. 2013;1 10:15109-14.

41. Williams GR, Bland R, Sheppard MC. Characterization of thyroid hormone (T3) receptors in three osteosarcoma cell lines of distinct osteoblast phenotype: interactions among T3, vitamin D3, and retinoid signaling Endocrinology. 1994;135:2375-85.

42. Luegmayr E, Varga F, Frank T, Roschger P, Klaushofer K. Effects of triiodothyronine on morphology, growth behaviour, and the actin cytoskeleton in mouse osteoblastic cells (MC3T3-E1). Bone. 1996;18:591-9.

43. Sperber GH, Sperber SM, Guttmann GD. Craniofacial embryogenetics and development. People Medical Publishing House, Shelton (CT); 2010. p. 37-60 and 131-144.

44. Tchounwou PB, Patlolla AK, Yedjou CG, Moore PD. Environmental exposure and health effects associated with malathion toxicity. IntechOpen. 2015. https://doi.org/10.5772/60911.

45. U.S. EPA (United States Environmental Protection Agency): Reregistration Eligibility Decision (RED) for malathion; EPA 738-R-06-030. Office of Pesticide Programs, U.S. Government Printing Office: Washington, DC. 2006.

46. Bonner MR, Coble J, Blair A, Beane-Freeman LE, Hoppin JA, Sandler DP, Alavanja MCR. Malathion exposure and the incidence of Cancer in the agricultural health study. Am J Epidemiol. 2007;166:1023-34.

47. Köch-Schulmeyer M, Ginebreda A, González S, Cortina JL, López de Alda M, Barceló D. Analysis of the occurrence and risk assessment of polar pesticides in the Llobregat river basin (NE Spain). Chemosphere. 2012;86:8-16.

48. Gómez-Gutiérrez Al, Jover E, Bodineau L, Albaigés J, Bayona JM. Organic contaminant loads into the Western Mediterranean Sea: estimate of Ebro River inputs. Chemosphere. 2006;65:224-36. 
49. Köck M, Farré M, Martínez E, Gajda-Schrantz K, Ginebreda A, Navarro A, Alda MLD, Barceló D. Integrated ecotoxicological and chemical approach for the assessment of pesticide pollution in the Ebro river delta (Spain). J Hydrol. 2010;383:73-82

50. Patnaik L. Biochemical alterations induced by sevin in Clarias batrachus. Asian J Exp Biol Sci. 2010;1(1):124-7.

51. Chowdhury MAZ, Fakhruddin ANM, Islam MN, Moniruzzaman M, Gan SH, Alam MK. Detection of the residues of nineteenpesticides in fresh vegetable samples using gas chromatography-mass spectrometry. Food Control. 2013; 34:457-65.

52. Karyab H, Mahvi AH, Nazmara S, Bahojb A. Determination of water sources contamination to diazinon and malathion and spatial pollution patterns in Qazvin. Iran Bull Environ Contam Toxicol. 2013;90:126-31.

53. Chatterjee NS, Banerjee K, Utture S, Kamble N, Rao BM, Panda SK, Mathew S. Assessment of polyaromatic hydrocarbons and pesticide residues in domestic and imported pangasius (Pangasianodon hypophthalmus) fish in India. Sci Food Agric. 2016;96:2373-7.

54. Sinha N, Lal B, Singh TP. Pesticides induced changes in circulating thyroid hormones in the fresh water catfish Clarias batrachus. Comp Biochem Physiol. 1991;100:107-10.

55. Ortiz-Delgado JB, Scala E, Arellano JM, Úbeda-Manzanaro M, Sarasquete C. Toxicity of malathion at early life stages of the Senegalese sole, Solea senegalensis (Kaup, 1858): notochord and somatic disruptions. Histol Histopathol. 2018;33:157-69.

56. Jarque S, Piña B. Deiodinases and thyroid metabolism disruption in teleost fish. Environ Res. 2014;135:361-75.

57. Barber LB, Lee KE, Swackhamer DL, Schoenfuss HL. Reproductive responses of male fathead minnows exposed to wastewater treatment plant effluent, effluent treated with XAD8 resin, and an environmentally relevant mixture of alkylphenol compounds. Aquat Toxicol. 2007:82(1):36-46.

58. Liu X, Ji K, Choi K. Endocrine disruption potentials of organophosphate flame retardants and related mechanisms in H295R and MVLN cell lines and in zebrafish. Aquat Toxicol. 2012;114-115:173-81.

59. Boglione C, Costa C, Giganti M, Cecchetti M, Di Dato P, Scardi M, Cataudella S. Biological monitoring of wild thicklip grey mullet (Chelon labrosus), golden grey mullet (Liza aurata), thinlip mullet (Liza ramada) and fathead mullet (Mugil cephalus) (Pisces: Mugilidae) from different Adriatic sites: meristic counts and skeletal anomalies. Ecol Indic. 2006;6:712-32.

60. Gisbert E, Ortiz-Delgado JB, Sarasquete C. Nutritional cellular biomarkers in early life stages of fish. Histol Histopathol. 2008;23:1525-39.

61. Mehrle PM, Mayer FL. Biochemistry/Physiology. In: Rand GM, Petrocelli SR, editors. Fundamentals of Aquatic Toxicology: Methods and Applications. USA: Taylor \& Francis; 1985. p. 264-82.

62. Newman SJ, Dunk $\sqcup$. Age validation, growth, mortality, and additional population parameters of the gold-band snapper (Pristipomoides multidens) of the Kimberley coast of northwestern Australia. Fish Bull. 2003:116-28.

63. Cook LW, Paradise CJ, Lomb B. The pesticide malathion reduces growth and survival in the development of zebrafish, Danio rerio. Envirom Toxicol Chem. 2005:24:1745-50

64. Draz AA, Samara IA, El-Sarha Al. Effects of chronic exposures to copper on production and total residues among tilapia species. B Natl I Oceanogr Fish. 1993;19:351-67.

65. Sweilum MA. Effect of sublethal toxicity of some pesticides on growth parameters, haematological properties and total production of Nile tilapia Oreochromis niloticus (L.) and water quality of pond. Aquacul Res. 2006;37:1079-89.

66. Hanson ML, Graham DW, Babin E, Azam D, Coutellec MA, Knapp CW, Lagadic $L$, Caquet $T$. Influence of isolation on the recovery of pond mesocosms from the application of an insecticide. I. Study design and planktonic community responses. Environ Toxicol Chem. 2007;26(6):1265-79.

67. Huynh H, Nugegoda D. Effects of chlorpyrifos exposure on growth and food utilization in Australian catfish, Tandanus tandanus. Bull Environ Contam Toxicol. 2012;88:25-9.

68. Snawder JE, Chambers JE. Critical time periods and the effect of tryptophan in malathion-induced developmental defects in Xenopus embryos. Life Sci. 1990;46:1635-42.

69. Snawder JE, Chambers JE. Osteolathyrogenic effects of malathion in Xenopus embryos. Toxicol Appl Pharm. 1993;121:210-6.

70. Higgs DA, Fagerlund UHM, McBride JR, Eales JG. Influence of orally administered L-thyroxine or 3,5,3'-triiodo-L-thyronine on growth, food consumption, and food conversion of underyearling coho salmon (Oncorhynchus kisutch). Can J Zool. 1979;57(10):1974-9.
71. Higgs DA, Fagerlund UHM, Eales JG, McBride JR. Application of thyroid and steroid hormones as anabolic agents in fish culture. Comp Biochem Physiol. 1982;73(B):143-76

72. Villalta M, Estévez A, Bransden MP. Arachidonic acid enriched live prey induces albinism in Senegal sole (Solea senegalensis) larvae. Aquaculture. 2005;245:193-209.

73. Hamre K, Opstad I, Espe M, Solbakken J, Hemre Gl, Pittman K. Nutrient composition and metamorphosis success of Atlantic halibut (Hippoglossus hippoglossus, L.) larvae fed natural zooplankton or Artemia. Aquac Nutr. 2002;8:139-48.

74. Sæle $\varnothing$, Solbakken JS, Watanabe K, Hamre K, Power D, Pittman K. Staging of Atlantic halibut (Hippoglossus hippoglossus L.) from first feeding through metamorphosis, including cranial ossification independent of eye migration. Aquaculture. 2004;239(1-4):445-65.

75. Soffientino B, Nacci DE, Specker JL. Effects of the dioxin-like PCB 126 on larval summer flounder (Paralichthys dentatus). Comp Biochem Physiol C Toxicol Pharmacol. 2010;152(1):9-17.

76. Narayan R, Joy KP, Sathyanesan AG. Cythion induced histophysiological changes in thyroid and thyrotrophs of the teleost fish, Channa punctatus (Bloch). Ecotoxicol Environ Saf. 1989;17:272-8.

77. Akhtar N, Kayani SA, Ahmad MM, Shahab M. Insecticide-induced changes in secretory activity of the thyroid gland in rats. J Appl Toxicol. 1996;16(5):397-400.

78. Kim S, Jung J, Lee I, Jung D, Youn H, Choi K. Thyroid disruption by triphenyl phosphate, an organophosphate flame retardant, in zebrafish (Danio rerio) embryos/larvae, and in GH3 and FRTL-5 cell lines. Aquat Toxicol. 2015;160:188-96.

79. Ortiz-Delgado JB, Ruane NM, Pousão-Ferreira P, Dinis MT, Sarasquete C. Thyroid gland development in Senegalese sole (Solea senegalensis Kaup 1858) during early life stages: a histochemical and immunohistochemical approach. Aquaculture. 2006;260:346-56.

80. Manchado M, Infante C, Rebordinos L, Cañavate JP. Molecular characterization, gene expression and transcriptional regulation of thyroid hormone receptors in Senegalese sole. Gen Comp Endocrinol. 2009;160(2):139-47.

81. Schnitzler JG, Frédérich B, Dussenne M, Klaren PHM, Silvestre F, Das K. Triclosan exposure results in alterations of thyroid hormone status and retarded early development and metamorphosis in Cyprinodon Variegatus. Aquat Toxicol. 2016b;181:1-10

82. Yadav AK, Singh TP. Pesticides induced changes in peripheral thyroid hormone levels during the different reproductive phases in Heteropneustes fossilis. Ecotoxicol Environ Saf. 1987;13:97-103.

83. Sinha N, Lal B, Singh TP. Thyroid physiology impairment by malathion in the freshwater catfish Clarias batrachus. Ecotoxicol Environ Saf. 1992:24:17-25.

84. Genever PG, Birch MA, Brown E, Skerry TM. Osteoblast-derived acetylcholinesterase: a novel mediator of cell-matrix interactions in bone? Bone. 1999:24:297-303.

85. Inkson CA, Brabbs AC, Grewal TS, Skerry TM, Genever PG. Characterization of acetylcholinesterase expression and secretion during osteoblast differentiation. Bone. 2004;35:819-27.

86. Patti A, Gennari L, Merlotti D, Dotta F, Nuti R. Endocrine actions of osteocalcin. Int J Endocrinol. 2013;2013(3):846480.

87. Shkil FN, Kapitanova DV, Borisov VB, Abdissa B, Smirnov SV. Thyroid hormone in skeletal development of cyprinids: effects and morphological consequences. J Appl Ichthyol. 2012;28:398-405.

88. Yoneda M, Takatsuki K, Yamauchi K, Oiso Y, Kurokawa M, Kawakubo A, Izuchi K, Tanaka H, Kozawa O, Miura Y. Influence of thyroid function on serum bone Gla protein. Endocrinol Japon. 1998;35:121-9.

89. Kojima N, Sakata S, Nakamura S, Nagai K, Takuno H, Ogawa T, Matsui I, Saru $\mathrm{H}$, Miura K. Serum concentrations of osteocalcin in patients with hyperthyroidism, hypothyroidism and subacute thyroiditis. J Endocrinol Investig. 1992;15:491-6.

90. Lerger J, Ruiz JC, Guibourdenche J, Kindermans C, Garabedian M, Czernichow P. Bone mineral density and metabolism in children with congenital hypothyroidism after prolonged -thyroxine therapy. Acta Paediatr. 1997:86:704-10.

91. Allain TJ, Yen PM, Flanagan AM, Mc Gregor AM. The isoform-specific expression of the tri-iodothyronine receptor in osteoblasts and osteoclasts. Eur J Clin Investig. 1996;26(5):418-25.

92. Sato $Y$, Nakamura R, Satoh M, Fujishita K, Mori S, Ishida S, Yamaguchi T, Inoue K, Nagao T, Ohno Y. Thyroid hormone targets matrix Gla protein gene associated with vascular smooth muscle calcification. Circ Res. 2005; 97(6):550-7. 
93. Gouveia CH, Schultz JJ, Bianco AC, Brent GA. Thyroid hormone stimulation of osteocalcin gene expression in ROS 17/2.8 cells is mediated by transcriptional and post-transcriptional mechanisms. J Endocrinol. 2001;170(3):667-75.

94. Marino G, Boglione C, Bertolini B, Rossi A, Ferreri F, Cataudella S. Observations on development and anomalies in the appendicular skeleton of sea bass, Dicentrarchus labrax L. 1758, lanae and juveniles. Aquac Fish Manage. 1993;24:445-56.

95. Hosoya K, Kawamura K. Skeletal formation and abnormalities in the caudal complex of the Japanese flounder, Paralichthys olivaceus. Bull Natl Res Inst Fish Sci. 1998;12:97-110.

96. Boglione C, Costa C, Di Dato P, Ferzini G, Scardi M, Cataudella S. Skeletal quality assessment of reared and wild sharpsnout sea bream and pandora juveniles. Aquaculture. 2003;227:373-94.

97. Gavaia PJ, Domingues S, Engrola S, Drake P, Sarasquete C, Dinis MT, Cancela ML. Comparing skeletal development of wild and hatchery-reared Senegalese sole (Solea senegalensis Kaup, 1858): evaluation in larval and postlarval stages. Aquac Res. 2009;40:1585-93.

98. Fernández I, Ortiz-Delgado JB, Darias MJ, Hontoria F, Andree KB, Manchado M, Sarasquete C, Gisbert E. Vitamin a affects flatfish development in a thyroid hormone signaling and metamorphic stage dependent manner. Front Physiol. 2017;8:458.

99. Geffen AJ, van der Veer HW, Nash RDM. The cost of metamorphosis in flatfishes. J Sea Res. 2007;58:35-45.

100. Bejarano-Escobar R, Blasco M, Degrip WJ, Oyola-Velasco JA, Martín-Partido G, Francisco-Morcillo J. Eye development and retinal differentiation in an altricial fish species, the senegalese sole (Solea senegalensis, Kaup 1858). J Exp Zool. 2010;314b:580-605.

101. Li Z, Ptak D, Zhang L, Walls EK, Zhong W, Leung YF. Phenylthiourea specifically reduces zebrafish eye size. PLoS One. 2012;7(6):e40132.

102. Negishi K, Sugawara K, Shinagawa S, Teranishi T, Kuo C-H, Takasaki Y. Induction of immunoreactive proliferating cell nuclear antigen (PCNA) in goldfish retina following intravitreal injection with tunicamycin. Dev Brain Res. 1991;63:71-83.

103. Graf W, Meyer DL. Central mechanisms counteract visually induced tonus asymmetries. A study on ocular responses to unilateral illumination. J Comp Physiol. 1983;150:473-81.

104. Schreiber AM. Asymmetric craniofacial remodeling and lateralized behavior in larval flatfish. J Exp Biol. 2006;209:610-21.

105. Lychakov DV. Anomalous otoliths of Black Sea fishes. Zh Evol Biokhim Fiziol. 1996:32:470-7

106. Sogard SM. Interpretation of otolith microstructure in juvenile winter flounder Pseudopleuronectes americanus ontogenetic development daily increment validation and so- matic growth relationship. Can J Fish Aquatic Sci. 1991;48:1862-71.

107. Helling K, Scherer $\mathrm{H}$, Hausmann S, Clarke AH. Otolith mass asymmetries in the utricle and saccule of flatfish. J Vestibul Res. 2005;15:59-64.

108. Brewster B. Eye migration and cranial development during flatfish metamorphosis: a reappraisal (Teleostei: Pleuronectiformes). J Fish Biol. 1987; 31:805-33.

109. Pittman K, Jelmert A, Naess T, Harboe T, Watanabe K. Plasticity of viable postmetamorphic forms of farmed Atlantic halibut, Hippoglossus hippoglossus L. Aquac Res. 1998;29:949-54.

110. Solbakken JS, Norberg B, Watanabe K, Pittman K. Thyroxine as a mediator of metamorphosis of Atlantic halibut (Hippoglossus hippoglossus L.). Environ Biol Fish. 1999;56:53-65.

111. OECD. Short guidance on the threshold approach acute fish toxicity. Paris: Organisation for Economic Cooperation and Development; 2010.

112. OECD. Fish toxicity testing framework. Paris: Organisation for Economic Cooperation and Development; 2012.

113. Cañavate JP, Fernández-Díaz C. Influence of co-feeding larvae with live and inert diets on weaning the sole Solea senegalensis onto commercial dry feeds. Aquaculture. 1999;174:255-63.

114. Ortiz-Delgado JB, Simes DC, Gavaia P, Sarasquete C, Cancela ML. Osteocalcin and matrix GLA protein in developing teleost teeth: identification of sites of mRNA and protein accumulation at single cell resolution. Histochem Cell Biol. 2005;124:123-30.

115. Bakke-McKellep AM, Koppang EO, Gunnes G, Sanden M, Hemre Gl, Landsverk T, Krogdahl A. Histological, digestive, metabolic, hormonal and some immune factor responses in Atlantic salmon, Salmo salar L., fed genetically modified soybeans. J Fish Dis. 2007;30(2):65-79.
116. Sirri R, Bianco C, De Vico G, Carella F, Bonaldo A, Sarli G, et al. Proliferation, apoptosis, and fractal dimension analysis for the quantification of intestinal trophism in sole (Solea solea) fed mussel meal diets. BMC Vet Res. 2014;10:148.

117. Lee CS, Georgiou T, Rode J. Proliferating cell nuclear antigen (PCNA) in pancreatic adenocarcinoma. Pathol Res Pract. 1993;189(5):527-9.

118. Gavaia PJ, Dinis MT, Cancela ML. Osteological development and abnormalities of the vertebral column and caudal skeleton in larval and juvenile stages of hatchery-reared Senegalese sole (Solea senegalensis). Aquaculture. 2002;211:305-23.

119. Wagemans F, Vandewalle P. Development of the bony skull in common sole: brief survey of morpho-functional aspects of ossification sequence. $J$ Fish Biol. 2001;59:1350-69.

120. Simes DC, Williamson MK, Schaff BJ, Gavaia PJ, Ingleton PM, Price PA, Cancela ML. Characterization of osteocalcin (BGP) and matrix Gla protein (MGP) fish specific antibodies: validation for immunodetection studies in lower vertebrates. Calcif Tissue Int. 2004;74:170-80.

121. Infante C, Matsuoka MP, Asensio E, Cañavate JP, Reith M, Manchado M. Selection of housekeeping genes for gene expression studies in larvae from flatfish using real-time PCR. BMC Mol Biol. 2008;9:28.

122. Livak KJ, Schmittgen TD. Analysis of relative gene expression data using realtime quantitative PCR and the $2^{-\Delta \Lambda C(T)}$ method. Methods. 2001;25(4):402-8.

\section{Ready to submit your research? Choose BMC and benefit from:}

- fast, convenient online submission

- thorough peer review by experienced researchers in your field

- rapid publication on acceptance

- support for research data, including large and complex data types

- gold Open Access which fosters wider collaboration and increased citations

- maximum visibility for your research: over $100 \mathrm{M}$ website views per year

At BMC, research is always in progress.

Learn more biomedcentral.com/submissions 